\title{
Prerequisites and initial developments for economic specialization in lagging regions-A study of specialized villages in Iran
}

\author{
Masoumeh Ghorbani $^{1}$ (D) Thomas Brenner $^{1}$
}

\begin{abstract}
Although the literature provides a huge number of studies on specialized regions, such as clusters and industrial districts, most of them concern developed regions. Studies that focus on the initial processes and preconditions for the emergence of economic specialization in lagging regions are rare, and studies of this kind considering a large number of cases not existing. We use the information on 140 villages in lagging rural regions in Iran to examine the initializing processes and preconditions as well as the connection between the two. We find that the conditions that are present in the region affect the potential initial processes and developments that might lead to specialization. Thus, the findings support the application of placebased policies.
\end{abstract}

Keywords Specialization - Clusters · Industrial districts · Rural area economy · Economic development · Iran

\section{JEL Classification R1 $\cdot \mathrm{O} 18$}

\section{Introduction}

In a world with increasing regional inequalities (Iammarino et al. 2019) knowledge about measures to improve the economic situation in lagging regions is especially important (e.g., Mokhayeri et al. 2020).

This topic has been increasingly taken up in the scientific literature. With the help of case studies and statistical analyses, many insights have been gathered and

Masoumeh Ghorbani

masomehghorbani@gmail.com

1 Department of Geography, Philipps-Universität Marburg, 35032 Marburg, Germany 
policy recommendations have been deduced (e.g., Stephens and Partridge 2011; Christiaensen et al. 2013; Gagliardi and Percoco 2017; Barzotto et al. 2020; Gaddefors et al. 2020; Rodríguez-Pose and Ketterer 2020; Wardenburg and Brenner 2020 among many others). This literature identifies a number of relevant aspects, such as local institutions, entrepreneurship, absorptive capacities, and collective agency.

The main finding is that there are no one-size-fits-all policies for lagging regions (e.g., Rodríguez-Pose and Ketterer 2020). A location-based policy perspective has been established in the literature (Barca et al. 2012; Barca 2019), which considers preconditions and dynamics as well as institutional and industrial settings. The effects of policy measures are assumed to be path-dependent in this literature, making location-based policy necessary. The smart specialization approach as well as the One Village One Product concept follows similar arguments (Foray 2014; Mukai and Fujikura 2015). This policy-related literature provides arguments and case-based evidence on preconditions for the development of local economic specializations and improvement.

While case studies provide various information on the preconditions and initial dynamics of regions that became economically successful, this information is put together in a meta-study, to our knowledge, only partly by Brenner and Mühlig (2013) so far, who did not focus on lagging regions. Of course, this knowledge has also found its way into theoretical works. For example, the most prominent cluster life-cycle model by Menzel and Fornahl (2010) describes the processes in the emergence stage of this life-cycle. However, as most of this literature, they focus on the processes taking place during this emergence and say little about why exactly this kind of cluster develops at this place. Path dependence and existing industry structures play an important role in this context. However, most of the current literature focusing on path-dependent processes studies diversification processes of firms, developments of new technologies and regional branching (e.g., Lorenzen 2005; Frenken and Boschma 2007). These processes are relevant for regions in which cluster or industries develop from an existing industrial basis. This literature is less informative about the original emergence of industrial activities in a region, although this is also a path-dependent process. In the early path-dependence literature, this original emergence is regarded as the result of chance events, which cannot be explained by the existing concepts and theories (Krugman 1991; Markusen 1996). The newer literature takes a more detailed look at the causes of path-dependence and discusses potential preconditions and pre-developments for new industries to appear in a region (e.g., Martin and Sunley 2006). Martin and Sunley also provide a list of potential preconditions, which can be partly applied also in the cases that we study. However, this literature as well as most of the empirical studies focus on developed countries.

What is missing in the literature is a structured analysis of the preconditions and initializing processes on the basis of data for numerous cases with successful development. Furthermore, a stronger focus on economically lagging locations in less developed countries is missing. We intend to fill both gaps by examining the following questions: How do lagging (rural) areas move from a situation with preentrepreneurial one-person economic and production activities to a situation with an agglomerated firm activity specialized in one industry? Which preconditions have 
been relevant for the transformation? What are the relevant early processes that initialize the development, and how do they depend on the preconditions and the industry that the region specializes in?

To this end, we examine 140 economically lagging villages ${ }^{1}$ in Iran that show specialization or some beginning specialization in the production of specific goods and are well documented. Hence, we are able to study the early development of these specializations as well as the characteristics of the locations. Our approach builds strongly on the meta-analysis by Brenner and Mühlig (2013) who have already distinguished and identified prerequisites, trigger events and self-augmenting processes. We deviate from their approach by considering only cases from one country and rather rural, economically lagging regions. Hence, we have a more homogeneous sample and are able to detect more commonalities within the considered cases. Furthermore, while Brenner and Mühlig (2013) had to rely on descriptions in the literature that in most cases judged the early development retrospectively, we use data and information often collected during the emergence phase of the industrial districts. Finally, the data is gathered and structured for all considered cases in the same way.

The remainder of the paper proceeds as follows. In Sect. 2 the existing theoretical concepts are described. The empirical approach is outlined in Sect. 3. Sect. 4 describes the identified precondition and initializing processes. Sect. 5 focuses on the relationship between preconditions and initial processes. The industries involved are examined in Sect. 6. Sect. 7 concludes and discusses options for policymakers.

\section{Theory and literature}

Multiple strands of literature are, in principle, relevant for our endeavor. These are the theories of industrial districts (Becattini 1990) and clusters (Porter 1990), the literature on regional path dependence (Bathelt and Boggs 2003) and windows of opportunities (Boschma 1996), and the policy-oriented concepts such as smart specialization (Foray 2014) and the "One Village, one product" model (Mukai and Fujikura 2015). While all these strands are helpful, none of them provides completely what we require. Since we study small geographical units-villages-the "One Village, one product" model fits best to our cases. However, the respective literature focuses mainly on policy issues and provides little information on preconditions and initializing processes. The concepts of regional path dependence and windows of opportunities are great theoretical foundations for the processes that we study, but so far, they are applied rather to larger, more developed geographical units, so that the knowledge gathered in their applications can only be partly transferred to our case. The cluster theory is designed for larger geographical units, but is the only one with a developed life-cycle theory which can be transferred to some extent to our case. Similarly, the theory of the industrial district focuses on larger units. Nevertheless,

\footnotetext{
1 They might have become small cities in the meantime, but have been villages when the processes leading to economic specialization started.
} 
the early Italian literature discusses many aspects and developments that are also relevant in our case.

In order to make clear that we borrow aspects and understandings from all the above strands of the literature instead of applying one of them, we call our cases "specialized villages" in the following. Since extensive literature exists on all these theories and concepts, we will focus more on what we borrow from each of them in the next subsection (2.1). We aim to identify potential preconditions and initializing processes for our empirical study. To this end, we use knowledge from all literature strands, which will be done for the preconditions in subsection 2.2 and for the initializing processes in subsection 2.3.

\subsection{Theoretical concepts}

One Village One Product (OVOP) The OVOP concept was developed for policy reasons in Japan (Mukai and Fujikura 2015). This approach aims at the production of at least one product in a village or small region based on the region's potential, to create jobs, to slow the exodus of young workers to large cities, and to provide the inhabitants with a viable economic livelihood. Therefore, the concept fits very well the cases that we analyze. Considering the basic idea it is related to the Smart Specialization Strategy that is applied especially within the EU (Foray 2018), but it is much more tailored towards rural regions in less developed countries. It is and was applied in many less developed countries in the last twenty years, but was also adapted usually to the respective case so that there is hardly a clearly defined approach (Kurokawa 2009; Denpaiboon and Amatasawatdee 2012). Furthermore, the scientific literature focuses on the evaluation of this policy's impact (Kurokawa 2009; Anh 2013; Mukai and Fujikura 2015). The initial developments, which we are interested in here, are not analyzed.

Cluster Most prominent is the definition of clusters by Porter (1990, 1998, 2000). However, many others have contributed to the understanding of the occurrence of (industry-specific) agglomerations. Benner (2009) provides a good overview of the underlying arguments and theories. While the general literature on clusters is of less interest for us due to the focus on larger geographical areas and most frequently on developed countries, the cluster life-cycle literature provides some transferable insights (Brenner 2004; Menzel and Fornahl 2010). According to this literature, the cluster life-cycle consists of four phases (Menzel and Fornahl 2010, p. 218): "emergence with only a few but growing numbers of mostly small firms, growth with a growing number of employees, ... sustainment, when the cluster is able to maintain its employment on a high level in more mature phases ..., [and] the declining stage". Due to path dependence in the life-cycle development, the stage of emergence is very decisive and often affects the development in later phases. In this context, some studies have listed and structured the preconditions and triggering factors in the initial phase of the cluster development (Fornahl et al. 2010; Elola et al. 2012; Brenner and Mühlig 2013; Isaksen 2016). These lists will be used in the following subsections. 
Industrial district While the concept of industrial districts originates from Marshall (1920), the literature on the North Italian districts made it prominent (e.g., Becattini 1990; Sengenberger and Pyke 1990). Becattini (1990) defined an Italian industrial district as "a socio-territorial entity which is characterized by the active presence of both a community of people and a population of small firms in one naturally and historically bounded area". This literature is interesting for us since most Italian cases have a non-metropolitan, small or medium-town environment, show a set of shared values like cooperation and collective identity, are influenced by strong social relations, and contain a local economic structure dominated by small entrepreneurs and skilled artisans (Becattini 1990; Zeitlin 1992). All this fits quite well with the cases we study, although the cities and regions studied in Italy are larger than our villages in Iran. Especially the older industrial district literature provides information on the preconditions and early developments, which will be used below, while the new literature focuses on restructuring and adaptation to global developments (e.g. Bathelt and Conserva 2018). A lifecycle approach to industrial districts is provided by Belussi and Sedita (2009).

Path dependence Path dependence has been used in the literature to explain the existence of business clusters and industrial districts (e.g. Kenney and Von Burg 2001; Bathelt and Boggs 2003). Especially the more recent literature treats the emergence of a new local industry not as an outcome of "chance" or "historical accident", but looks at the exact factors affecting path dependence (Glasmeier 2000; Martin and Sunley 2006). In this context, "preexisting resources, competencies, skills, and experiences that have been inherited from previous local paths and patterns of economic development" (Martin 2010, p. 20) might stimulate or enable the emergence of new local activities. Martin and Sunley (2006, Table 4) name explicitly a number of possible sources in the context of regional path dependence: "natural resource-based, sunk costs of local assets and infrastructures, local external economies of industrial specialization, regional technological 'lock-in', economies of agglomeration, region-specific institutions, social forms and cultural traditions, and interregional linkages and interdependencies". Some of these are relevant also for our cases and are discussed further below. Furthermore, the literature on path creation and path development is relevant. In this literature, human action is more central with actor deliberately deciding about the path of the future (Garud and Karnøe 2001). It is used in several works to expand the understanding of new regional industrial path development (Trippl et al. 2018; Hassink et al. 2019; MacKinnon et al. 2019; Grillitsch and Sotarauta 2020). Several kinds of crucial local actors are identified (Grillitsch and Sotarauta 2020), which are taken up below.

Windows of Locational Opportunity (WLO) The WLO concept builds on the works by Scott and Storper (Scott and Storper 1987; Scott 1988) and argues that development options (in form of new technologies or industries) open up at a certain time and can be utilized within regions. Boschma (1996) argues, based on this model, that even lagging regions obtain due to industrial or technological discontinuity and major innovations the option for economic development. Leading regions are often not in a good position to follow such disruptive developments (Boschma 1996), 
while newly emerging firms often play an important role (Dosi 1982). Depending on human agency and historical accidents_-which might be seen as random events-, so far not-leading regions might develop into leading regions. However, this seems rather to apply to lagging regions in well-developed countries.

\subsection{Potential preconditions}

We follow Brenner and Mühlig (2013) in distinguishing between prerequisites, triggering events and self-augmenting processes. Due to our interest in the early developments, we ignore self-augmenting processes here and start with the preconditions (triggering events are discussed in Sect. 2.3). All the different strands of literature presented above agree on the fact that certain preconditions have to be given for the emergence of local economic specialization. A list of preconditions is given by Brenner and Mühlig (2013). We start from this list, but structure them into five categories: Social and institutional preconditions, economic tradition, location specificities, market situation, and policy. Furthermore, we include further literature and discuss the relevance to our cases.

\subsubsection{Social and institutional preconditions}

Brenner and Mühlig (2013, p. 485) list (social) networks, culture and historical preconditions among their prerequisites. All of these originate from the early works on industrial districts and clusters (e.g., Becattini 1990; Storper 1995), highlighting the relevance of interaction, proximity and information exchange as well as "untraded interdependence", including aspects such as conventions, habits and informal rules. Granovetter (1985) framed the notion of "social embeddedness" in this context. Numerous papers exist that explain the relevance of culture and social networks to regional development (e.g., Storper 1995; Brautigam 1997; Pilon and DeBresson 2003). While culture surely plays a role, we will focus on social networks here (also due to data limitations). The importance of social networks, in the form of interpersonal relations and ethnic and kinship ties, has also been repeatedly confirmed in developing countries (e.g., Brautigam 1997; Fan and Scott 2003).

\subsubsection{Economic tradition}

Brenner and Mühlig (2013, p. 485) list industrial structure and tradition as prerequisites. The emergence of industrial districts and clusters is frequently described as a bottom-up process based on activities present in the region (e.g., Cappellaro et al. 2020; Fan and Dai 2017; Canello and Pavone 2016), which is confirmed by many case studies (e.g., Brusco and Malagoli 1981; Sforzi 1989; Ottati 1994; Krugman 1991). Similar arguments are put forward in the literature on path-dependence: Martin and Sunly (2006, Table 4) name the "development of a distinctive specialized regional technological regime or innovation system through processes of local collective learning, mimetic and isomorphic behavior, dedicated technology and research organizations, interfirm division of labor and other forms of technical interrelatedness" as a source of path-dependence. Part of these arguments relates to 
a given industrial structure and a diversification into related economic activities. In contrast, we study locations without a relevant local firm-based activity before, so that no industrial structure is present. Nevertheless, people in the studied villages have common historical legacies, traditions, and culture that can be reflected in, for example, craft skills inherited from their ancestors (Belussi and Sedita 2009; Elola et al. 2012; Belussi 2015). Connected to the original situation based on craftsmen and artisans, which are often homeworkers supported by family members, is a repeatedly found situation of informal economics (e.g., Brusco and Malagoli 1981; Akoten et al. 2006). This decreases production costs due to avoiding taxes and social welfare payments. Such a situation and the resulting spin-offs through family relationships are found to be important, especially in less developed countries (e.g., Li et al. 2011).

\subsubsection{Location specificities}

Many location characteristics can be important for the emergence of cluster, industrial districts, or local specialization. Brenner and Mühlig (2013) list ten such factors: qualified labor, wages, university and public research, suppliers, local capital market, geographic location, transportation infrastructure, quality of life, urbanization, and technology parks. A number of these factors are not relevant to our cases. Rural villages in less developed countries do not contain universities, public research institutes, a local capital market, technology parks or a high quality of life. Furthermore, there is per definition no urbanization. Since we look at the first development of a firm-organized economic activity, there are also no suppliers present. However, related to this there might be resources present that are necessary inputs to production, a factor not highlighted by Brenner and Mühlig (2013). Another factor neglected by them are land prices. Hence, we discuss the following four factors and the related literature: local resources, land prices, available labor, and geographic location/transport possibilities.

Martin and Sunley (2006) called one kind of path dependence "natural resource based". Especially in less developed locations, local resources are an important precondition for economic development. The resources might consist of specific raw material, specific conditions for agriculture, or specific natural or man-made features that make a region interesting for tourism.

Krugman and Elizondo (1996) state that by lower costs, such as lower land prices and wages, rural areas might outweigh the centripetal forces of urban areas. This allows for industrial development and production for larger firms also in the case of small enterprises or even household producers (e.g., Weijland 1994; Pedersen 1997; Sato 2000; Fan and Qin 2005; Ohno 2009; Das 2011; Huang et al. 2008).

The labour force available in a region is an important precondition for economic development and the emergence of clusters or industrial districts in many ways (Brenner and Mühlig 2013). Especially in less developed regions, low wages are important and often mentioned in the literature (Brenner and Mühlig 2013). For example, Hashino and Otsuka (2013) found in their case studies on Japan that access to a flexible, cheap and non-regulated workforce is important. This shows that the factor goes beyond wages and contains also the availability, which implies 
that unemployment and income perspectives in the region also matter. Concerning labour force, qualified labor is also very often mentioned as a prerequisite in the literature (Brenner and Mühlig 2013). However, this applies to rather well-developed locations and high-tech economic activity. In less developed rural areas, this seems to be less relevant, but returning qualified labor might be an issue.

An advantageous geographic location in relation to other locations due to distances or transportation options is a factor often mentioned in the literature (Brenner and Mühlig 2013). This applies rather to centrally located cities or important harbors and seems not relevant for the cases studied here. However, the access to centers determined by the distance to them might be an issue.

\subsubsection{Market situation}

Local demand was argued to be an important factor in Porter's cluster theory as well as in the industrial district literature and confirmed in many case studies (Porter 1990; Brenner and Mühlig 2013). We will distinguish different aspects here. First, the initial economic activity might be a response to existing non-local opportunities and demand (Viederyte 2018). Often this happens in the form of satellite industrial platforms (Jucevicius and Grumadaite 2015) or integration in value chains (e.g., Huang et al. 2008) due to cost advantages (this is already included above). Second, some studies identify specific local demand as the basis for industrial development (Elola et al. 2012; Viederyte 2018). The argument is that based on the local demand competencies and production capacities (indigenous technologies) are developed that are then used to also supply demand outside the area (Ohno 2009).

\subsubsection{Policy}

Brenner and Mühlig (2013) list local as well as national policies as prerequisites for cluster development. However, this does not include specific policy measures to create or support the development of clusters (which they classify as triggering events). Policy as a prerequisite is the basic local or regional policy orientation, including general policy support not specifically conducted to support one specific cluster. Since we look for local preconditions, this general policy orientation might be an issue.

\subsection{Potential initializing processes}

Again, we start from the triggering events identified by Brenner and Mühlig (2013): Crucial innovations, promoting activities, specific policy measures, historical events, and the founding of leading firms. Crucial innovations can be taken by existing firms or by start-ups. The former is not relevant in our cases, in which we study the first establishment of registered firms. Therefore, we merge this triggering event with the founding of leading firms under the heading "innovative entrepreneur". All triggering events are discussed from a process perspective in the following, using further literature. 


\subsubsection{Innovative entrepreneur}

In the context of industrial districts and clusters, the literature frequently highlights the importance of an actor who identifies and exploits given opportunities by founding a firm, which might become so influential that spin-offs and economic growth result in the region (Harris 2020; Garavaglia 2018; Belussi 2015; Brenner and Mühlig 2013; Elola et al. 2012; Belussi and Sedita 2009). In latecomer and lagging regions, such firms might motivate the creation of many small firms that copy the business idea of the first firm or serve the anchor firm in a "hub and spoke"-like structure (Jucevicius and Grumadaite 2015). We will distinguish two kinds of innovative entrepreneurs, according to their origin: The person realizing the opportunity and starting the first firm might origin from within the region, which we call local innovative entrepreneur, or from outside the area, which we call outside investor. In the latter case, the investors might be MNCs (Multi-National Corporations) investing in the region. According to Viederyte (2018), such investments and the connected knowledge flow into a region might trigger the emergence of industrial districts and clusters (see also Belussi 2015; Elola et al. 2012). However, it might be also done by an individual entrepreneur who realizes a specific opportunity in the region.

\subsubsection{Promoting activity}

Grillitsch and Sotarauta (2020) found three types of change agencies that can play a significant role in the utilization of opportunities and the change of regional development paths: placed-based leadership, institutional entrepreneurship, and innovative entrepreneurship. Innovative entrepreneurship represents what we discussed above as "local innovative entrepreneur". Institutional entrepreneurship does not play a role in our studied cases. This is due to the fact that we study villages that do not contain intermediaries, associations, or institutions that are usually involved in the respective institutional changes (Grillitsch and Sotarauta 2020).

Grillitsch and Sotarauta (2020) define placed-based leadership as capturing "actions that aim at transforming particular places by pooling competencies, powers, and resources to benefit both agents' individual objectives and a region more broadly". They argued that actions by many people are involved, as well as people coordinating the activities in the region. While we do not observe the coordinating hand in our cases, collective action based on individual objectives but serving the area are found frequently. This is caused by a common understanding of opportunities based on many pre-entrepreneurial one-person firms (businesses run by one person with the support from family members, see Weijland 1994) that already existed before. Such joint economic development is repeatedly observed in case studies (e.g., Gibbs and Bernat 1997; Mottaleb and Sonobe 2013). We call this process 'common promotion', signifying that many people act quite simultaneously. Although this is not coordinated, it can be seen as the "coordination effects" that Martin (2010) emphasizes.

In the context of our aim to connect preconditions with initializing processes, it is interesting to further distinguish the case of the common promotion on the basis of the kind of economic activity that is developed in the region. Since it builds 
on existing pre-entrepreneurial one-person firms, we are able to distinguish three categories according to these firm's activities/origin:

- Tourism-related: Attractive locations or interesting spots provide the opportunity to start pre-entrepreneurial one-person firms offering tourism-related services. This can build the starting point for increasing activity in the tourism sector as shown in various studies (e.g., Nylander and Hall 2005; Hall 2005; Ohe 2019; Voronkova et al. 2019).

- Specific needs-based: Some locations have specific conditions (related to weather, culture, and history) that cause specific needs. One-person firms emerge that produce the respective good. In this case, originally there is no market outside the location or, at least, outside the area. For the local industry to grow, such markets have to be developed.

- Endowment-based: Local resources provide the opportunity to process them or use them for production on the spot. Of course, the resources can also be transported and further processed elsewhere. However, they provide the opportunity for oneperson firms to utilize them for production, usually originally for the local market (see, e.g., Gibbs and Bernat 1997).

\subsubsection{Specific policy measure}

Benner (2009) states that intervention by policymakers can facilitate regional evolution and result in the emergence of clusters. There are plenty of examples of cases of cluster development with significant contributions by specific policy measures (Brenner and Mühlig 2013). Policy measure can be conducted bottom-up, which is often applied in Europe, and top-down, which is more frequent in Asia (Sopoligová and Pavelková 2017). A policy measure often applied in developing countries or remote places is the concept of One Village One Product (e.g., Chidumu 2007; Mukai and Fujikura 2015; Sega and Kanichiro 2018; Hoang et al. 2018; Li and Schumann 2013; Natsuda et al. 2012).

\subsubsection{Historical event}

Historical events that influence the development of regions can be of various kinds, ranging from wars to natural disasters and the movements of capital cities. They are very specific and differ strongly in the processes they imply so that we do not discuss them in more depth here. In addition, they do not matter in our cases.

\section{Empirical approach}

Our analysis focuses on economically lagging small-scale areas that specialized in producing particular goods. The main question to be answered is how and based on which initial conditions specialization has emerged in these places. Therefore, the potential preconditions and initializing processes have been deduced from the 
literature above. We want to examine their presence in a large number of cases, for which similar and comprehensive data are given.

\subsection{Data}

The Iran Small Industries and Industrial Parks Organization (ISIPO) publishes reports that provide information about all clusters that they identify in Iran. In the latest report that we use (February 2018) lists 429 cases. This list contains actual and potential clusters and the ISIPO monitors their development phase using the UNIDO methodology (Hogg 1978; Deputy of Small Industries of ISIPO 2016). They define a business cluster as an active group in one business field that is concentrated in a geographical area, has the ability to work together to complement each other's activities and has common challenges and opportunities. The reports encompass "Cluster Maps" for the Provinces of Iran, feasibility studies of each identified potential cluster, and a diagnostic study of the clusters. While the reports contain all kinds of specialized locations under the heading of "cluster", we are specifically interested in specialized villages in rural areas (see above). This results from the scientific interest in these so far rarely analyzed types, but also from the more practical reason of data availability. The earliest available report dates from the year 2007. To examine preconditions and initial processes, information that is obtained during the embryonic, forming stages provides a more reliable data source. Hence, clusters in cities have usually been established long ago. In fact, the reports show that many clusters have originally emerged in small villages and, as a consequence of the economic success of the specialization, these villages have developed into cities over time.

We apply the following conditions to identify the fitting cases (conditions a and $b$ are checked for the time declared by the ISIPO reports at the time when cluster emergence started; condition $\mathrm{c}$ is checked for the most present time):

a. The analysis is limited to villages (defined in Iran as having less than 10000 inhabitants);

b. The case has to be located in economically lagging areas along with no sufficient infrastructure (the used proxies are: 1. No financial and technical support institutes exist in the village; 2 . No registered firm with more than 10 employees exists; 3. Below-average share of educated employees (compared with the national average rate: $23.9 \%$; Statistical Center of Iran 2019) $)^{2}$;

c. The majority (more than 50\%) of local employees has to be employed in the production of one particular good (local economic specialization).

The required information is taken from the published ISIPO reports. 140 of the 429 regions within the ISIPO reports satisfy the above conditions ${ }^{3}$. The location of these cases within Iran is shown in Fig. 1.

\footnotetext{
2 In case that data on one of the proxies is missing, the decision is based on other proxies only.

3 Our analysis focuses on the initial processes and the precondition so that we used the reports with the relevant information on each case independent of their publication date.
} 


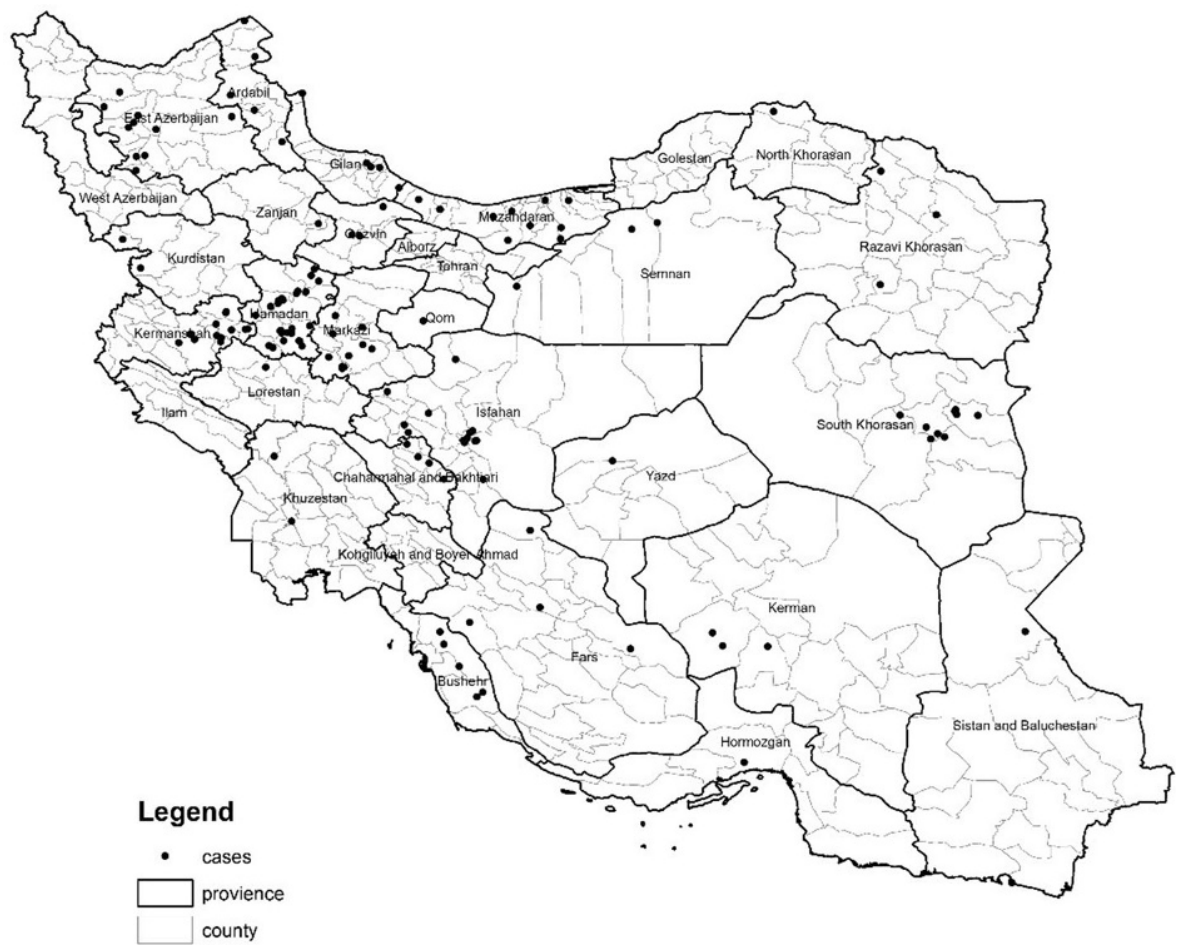

Fig. 1 Location of the 140 studied cases

The analysis of these 140 villages is mainly based on the ISIPO reports. The project managers within the ISIPO write the reports according to a given structure, which requires them to answer ten questions (described in Appendix I). To answer these questions, the respective authors, use three data sources:

1. Interview with experts and provincial officials ${ }^{4}$ about the presence or absence of clusters in the province and the early developments;

2. Available documents, such as official reports of related organizations and departments and formal academic research;

3. Interview with the stakeholders of each cluster, such as main firms, associations, unions, raw material suppliers, product sellers, and business development service providers.

The first two sources are used to answer question 1, while the interviews with stakeholders are used to answer questions 2-10 (questions given in Appendix I).

\footnotetext{
4 Officials from the province are the Managing Director or Deputy of Small Industries, Governor or his representative, representative of the Plan and Budget Organization, representative of the Organization of Industries, Mines and Commerce, representative of the General Department of Cooperatives, representative of the Agricultural-Jahad Organization, representatives of banks, representative of the Labor and Social Affairs Organization, representative of the organization or general administration (Deputy of Small Industries of ISIPO, 2016). In some cases, experienced experts or experts in the field of clusters are included.
} 
The reports are written repeatedly, and we use for each case the report that is nearest to embryonic, forming stage of the case (the stage is classified and provided in the reports). We use reports for the years 2007-2018, while the emergence of the considered clusters falls in a much greater period of time, with some already emerging in the 1960s while others just emerged. Hence, we are able to use the reports from the embryonic in some cases, forming stage, while in other cases we have to use later reports (which contain the description of the early stages). It can be expected that the people interviewed for the conduction of the reports have experienced the relevant developments. Nevertheless, the possibility that the reports are biased due to ex-post rationalization exists and is probably more severe in cases in which the developments have been far in the past. The fact that many very different stakeholders are interviewed for the reports should reduce this bias and make the reports more objective. However, of course, we rely on the carefulness of the people conducting the reports. Nevertheless, we see it as a strength of our study that we are able to include many cases that are examined in the same way and based on heterogeneous information from various knowledgeable governments and local and non-local stakeholders. Furthermore, the reports are done by a specialized organization (ISIPO) with trained interviewers (CDAs), which should result in the high quality of the used data.

In some cases, we encountered missing data in the reports: Sometimes the functioning of local businesses is not sufficiently described. Additional sources-many official publications by local organizations on the internet-have been used in these cases (the sources are listed in Appendix II). These sources have been also used to check and, in some cases, clarify the factors involved in the emergence of the clusters. Furthermore, in nine cases, an interview has been done with available CDAs to fill in other missing data and clarify the initial developments.

\subsection{Methodology}

Our methodological approach is straightforward. Above, we deduced from the literature all preconditions and initializing processes that might be relevant for our cases. These preconditions and initializing processes are listed in the following and the information (mainly from the ISIPO reports sometimes supplemented by additional information) used to identify their presence is explained:

\subsubsection{Preconditions}

Social networks The relevance of family ties is stated in the ISIPO reports within the description of the history of the clusters (question 2.5, see Appendix I). Family ties are regarded to be involved if the description mentions the relevance of family members in business activities. Examples are explicit statements of the "participation of family members" or statements such as "working with the family ... has brought flexibility in the number of work hours" and "children learned this field of activity by playing in family firms". 
Craft skills Within the ISIPO reports the type of production is classified (question 2.4, see Appendix I) and the origin of the production activity is described (question 2.5, see Appendix I). This allows us to identify whether the cluster activity is based on traditional skills that have been present before.

Informal economics The descriptions of the emergences of the clusters in the ISIPO's reports (question 2.5, see Appendix I) often contain explicit statements about the lack of tax and insurance payments in their embryonic state. It is argued in the reports that this is done to "reduce side costs", for "price competitiveness" and in some cases, it is even an argument for the businesses' return to their villages. In addition, question 9.6 (Appendix I) provides the share of insured workers. If this is zero in the embryonic state, it is a clear sign for informal economics.

Local resources In order to identify whether local resources play an important role, several parts of the ISIPO reports are used. Question 10.1 provides information about the importance of resources and raw materials, while question 4 provides more detailed information on the used materials (4.1 and 4.2) and their origin (4.4 and 4.5, see Appendix I). Finally, the role in the emergence of the cluster is described in question 2.5. In addition, we collect information about the further characteristics of the local resources by considering whether they fulfil the following two conditions:

- High-quality local material: We consider the local raw materials to be of high quality if this is mentioned as a strength of the cluster in the ISIPO report (question 1.5, see Appendix I). Furthermore, in some cases, the high quality of local raw materials is also mentioned in the description of the history of the cluster (question 2.5).

- Perishable resources: Whether the resources used are perishable is detracted from the description of the raw materials in the ISIPO report (question 4.1, see Appendix I). In some cases, the description of the history adds to this (question 2.5).

Lower land prices We consider land prices to be an issue in the emergence of the industrial districts if either this is mentioned in the history description (question 2.5 ) or if it is presented as a strength of the region (question 1.5, see Appendix I) in the ISIPO reports. In the used additional internet sources, this is called "One House, One Firm" model.

Low wages Low wages are defined to be a factor if they are mentioned in the description of the history in the ISIPO reports (question 2.5). In these reports, it is often mentioned that the local workers had accepted low wages and that this caused low production prices and competitiveness in the market. The relevance of this factor was a central aspect that has been checked by interviewing the responsible CDAs.

Unemployment We consider unemployment to be a factor if this is explicitly mentioned in the description of the history in the ISIPO reports (question 2.5). Typical formulations are stating the "lack of alternative jobs" or "unemployment in the village" as driving factors. Furthermore, in the description of the further development, 
it is often reported that "zero unemployment" is reached or that "reverse migration" takes place due to job opportunities.

Income perspectives In some ISIPO reports, the option to improve the own income and the easiness to start a business are mentioned as relevant factors in the emergence of the cluster (question 2.5, see Appendix I). Typical arguments reported circle around "making more money in the field", "less investment required", and that the processes are less difficult.

Returning qualified labor In some ISIPO reports, the return of local skilled people, who collected experience in the non-local often industrial areas or vocational training centers is described as a turning point in the emergence of a "new field of activity" (question 2.5). In this case, we consider this factor as relevant.

Access to centers While the information on the closeness to main cities is directly given in the ISIPO reports (question 5.3, see Appendix I), we consider it as a factor if it is also mentioned in the description of the history (question 2.5), as a strength of the location (question 1.5) or as a factor that the cluster relies on (question 10.1).

Local demand The ISIPO reports provide detailed information about the demand for the products of the districts and especially on its spatial distribution (question 7). A local market is considered to be crucial if it is also mentioned as an important factor in the history description (question 2.5) or as a factor the cluster relies on (question 10.1, see Appendix I). In order to further characterize the production related to the local demand, we check whether the following characteristic is given:

- Qualified production: Information on the quality of the products is explicitly given in the ISIPO reports (question 6.5, see Appendix I). We consider this to be a crucial factor if it is also mentioned in the history description (question 2.5) or as the strength of the cluster (question 1.5). Typical arguments in the reports are that due to the quality the regions attracted outside buyers or the producers had been competitive in outside markets.

General policy Whether general policy was involved is described in the question on the history of the region (2.5). There we find cases with local people benefiting from general financial supports of establishing businesses in villages and government support on particular strategic products.

\subsubsection{Initializing processes}

Local innovative entrepreneur Whether one local person started the first firm with other locals following is mentioned in the description of the history (question 2.5). Usually, it is explained in the report that this person had higher knowledge of the market, more external connections to the resource and sales market or connections to the government or financial institutions. By this, we have a clear indication that one entrepreneur started well before all other local entrepreneurs. 
Outside investor Whether the first firm was started by someone coming from outside the area is also mentioned in the description of the history (question 2.5). In these cases, the first main actor is located outside the village, providing the required capital to produce locally, as well as paying for labor, taking the goods from the manufacturer, and selling them as the first seller.

Common promotion Whether there was a joint movement from pre-entrepreneurial one-person firms to larger firms is mentioned in the description of the history (question 2.5). In addition, we identify with the help of the answers to questions 2.1, 4.3, and 10.1 whether the original pre-entrepreneurial one-person firms were

- Tourism-related: in these cases, we find in the reports the relevance of tourism destinations and the establishment of hostels and tour agencies.

- Specific needs-based: in these cases, we find descriptions of the emerging of a bigger market from an originally only local market and the description of related development in the production process.

- Endowment-based: in these cases, we find the importance of local resources declared in the reports.

Specific policy measure Whether a cluster received governmental support is explicitly stated in the ISIPO reports (question 8.6, see Appendix I). The importance of this support is described in the question on the history of the region (2.5). However, this is only found in one case where the government supported the initial process by specific education measures.

Historical events We found no case in which some specific historical events are mentioned in the description of the history (2.5). We conclude that this is not a relevant initializing process in our sample.

For each of the above 15 preconditions and seven initializing processes (distinguishing "common promotion" according to the three sources), we checked whether they have been present in the 140 studied cases.

\section{Descriptive statistics}

Before we analyze the relationships between initializing processes and precondition as well as industries in the next two sections, we will have a first look at how often the different precondition (4.1) and initializing processes (4.2) are present in our cases.

\subsection{Preconditions}

Table 1 lists the presence of the 15 potential preconditions deduced from the literature in our 140 empirical cases. We find that four preconditions are given in most cases: Social networks, informal economics, low wages, and unemployment. The former two are related to the village characteristics of our cases, while the latter two are related to the missing economic activity before the emergence of economic 
Table 1 List of preconditions and their presence

\begin{tabular}{lll}
\hline Precondition & $\begin{array}{l}\text { Number of } \\
\text { observations }\end{array}$ & $\begin{array}{l}\text { Number of cases } \\
\text { with presence }\end{array}$ \\
\hline Social networks & 139 & 138 \\
Informal economics & 140 & 123 \\
Low wages & 140 & 121 \\
Unemployment & 139 & 114 \\
Local resources & 140 & 97 \\
Lower land prices & 140 & 97 \\
Local demand & 140 & 64 \\
Craft skills & 140 & 54 \\
Returning qualified & 140 & 37 \\
labor & & \\
Qualified production & 140 & 29 \\
High quality local & 140 & 23 \\
material & & \\
Perishable resources & 140 & 22 \\
Income perspectives & 140 & 21 \\
Access to centers & 140 & 9 \\
General policy & 140 & 3 \\
\hline
\end{tabular}

specialization. In contrast, two preconditions are present only in a few cases: General policy and access to the centers. While the latter shows that we have many quite remote places in our sample, the missing general policy shows that in most cases there are no policy institutions in the area that are able to support economic development.

\subsection{Initializing processes}

Table 2 lists the presence of the seven potential initializing processes in our cases. It has to be mentioned, that the first five initializing processes are defined disjunctively so that only one of them can be present, while the latter two could occur together with any other. Interestingly, we find specific policy measures involved in only one case. This confirms the above finding that local policy institutions are missing that might trigger economic development. It also shows that there was also no political engagement to promote development in these locations on a higher level. The ISIPO reports also show that policy was involved later, once the economic specialization had developed, but not in triggering the development. Historical events played no role in our sample.

In most of the cases (89) there was no one actor, but joint action of many people in the village. Well in line with many arguments in the literature-especially the path creation literature stating "coordination effects" (Martin 2010), but also the Windows of Locational Opportunity literature-many one-person firms, influenced by each other, took the entrepreneurial step to develop their firm further. This "joint" action is based on common perception about the given advantageous conditions and the adequate strategies to use them within the local communities. This caused the 
Table 2 List of initializing processes and their presence

\begin{tabular}{lll}
\hline Precondition & $\begin{array}{l}\text { Number of } \\
\text { observations }\end{array}$ & $\begin{array}{l}\text { Number of cases } \\
\text { with presence }\end{array}$ \\
\hline $\begin{array}{l}\text { Local innovative } \\
\text { entrepreneur }\end{array}$ & 140 & 47 \\
$\begin{array}{l}\text { Outside investor } \\
\text { Common promotion }\end{array}$ & 140 & 4 \\
$\begin{array}{l}\text { Tourism-related } \\
\text { Specific needs-based }\end{array}$ & 140 & \\
Endowment-based & 140 & 19 \\
General policy & 140 & 23 \\
Historical events & 140 & 47 \\
\hline & & 0 \\
\hline
\end{tabular}

involvement of a large share of the local population in the production of a particular good. The economic development in these cases is strongly embedded in the local community. We distinguish three different types of advantageous conditions involved (see above): tourism-related potentials, pre-entrepreneurial production activities based on specific needs in the region, and specific endowments in the region. All these types play a role, while the latter is most frequent.

Outside investors are only found in very few cases. The remoteness and smallness of the places seem to make this unlikely. Quite frequent (47) are cases in which one member of the local community acts as an innovative entrepreneur and develops the first larger business. This generates a turning point in the given local economy. The innovative entrepreneur utilizes location characteristics to produce for an outside attractive market. Others, after observing the success of the first entrepreneur, follow the created business path.

\section{Relation between preconditions and initializing processes}

If policymakers intend to support the initializing processes that can lead to a successful economic specialization in lagging regions, it is important to know which processes can work and what preconditions have to be given. To this end, we examine the relationship between preconditions and initializing processes in the following.

In line with the descriptive findings in section four, we distinguish five initializing processes and 13 preconditions that are frequently found in our cases (excluding the two preconditions, general policy and access to the center, which are so rare that no conclusions are possible). Chi-square tests are used to identify the preconditions that differ for the five initializing processes. For 11 preconditions, significant differences are detected by the chi-square test. For these preconditions (Table 3), a Post-Hoc test (according to Beasley and Schumacker 1995 and Garcia-Perez and NunezAnton 2003) is used to examine for which type of initializing processes they are more frequently present.

The shares of cases in which the preconditions are present in each type of initializing process are given in Table 6 in Appendix V. One precondition is present in all cases, except for tourism-related common promotion: Low wages. This is not 
Table 3 Preconditions with significant differences between the types of initializing processes and their relation to these types (Post-Hoc test adjustment residual $\mathrm{Z}$; $p$-value in bracket)

\begin{tabular}{|c|c|c|c|c|c|c|}
\hline \multirow[t]{2}{*}{ Precondition } & \multirow{2}{*}{$\begin{array}{l}\text { Chi- } \\
\text { square } \\
\text { test: } p \text { - } \\
\text { value }\end{array}$} & \multicolumn{5}{|c|}{ Initializing processes } \\
\hline & & $\begin{array}{l}\text { Common } \\
\text { promotion: } \\
\text { tourism-rel }\end{array}$ & $\begin{array}{l}\text { Common } \\
\text { promotion: } \\
\text { needs- } \\
\text { based }\end{array}$ & $\begin{array}{l}\text { Common } \\
\text { promotion: } \\
\text { endowment- } \\
\text { based }\end{array}$ & $\begin{array}{l}\text { Local } \\
\text { innov. en- } \\
\text { trepreneur }\end{array}$ & $\begin{array}{l}\text { Outside } \\
\text { investor }\end{array}$ \\
\hline Craft skills & $<0.01$ & $\begin{array}{l}-3.715 \\
(0.000)\end{array}$ & $\begin{array}{l}3.34 \\
(0.001)\end{array}$ & $\begin{array}{l}6.938 \\
(0.000)\end{array}$ & $\begin{array}{l}-6.665 \\
(0.000)\end{array}$ & $\begin{array}{l}-0.566 \\
(0.571)\end{array}$ \\
\hline $\begin{array}{l}\text { Informal } \\
\text { economics }\end{array}$ & $<0.01$ & $\begin{array}{l}1.743 \\
(0.081)\end{array}$ & $\begin{array}{l}-2.24 \\
(0.025)\end{array}$ & $\begin{array}{l}3.127 \\
(0.002)\end{array}$ & $\begin{array}{l}-2.352 \\
(0.019)\end{array}$ & $\begin{array}{l}-0.799 \\
(0.424)\end{array}$ \\
\hline $\begin{array}{l}\text { Local re- } \\
\text { sources }\end{array}$ & $<0.01$ & $\begin{array}{l}3.122 \\
(0.002)\end{array}$ & $\begin{array}{l}0.032 \\
(0.974)\end{array}$ & $\begin{array}{l}5.6 \\
(0.000)\end{array}$ & $\begin{array}{l}-6.814 \\
(0.000)\end{array}$ & $\begin{array}{l}-3.048 \\
(0.002)\end{array}$ \\
\hline $\begin{array}{l}\text { High quality } \\
\text { local material }\end{array}$ & $<0.01$ & $\begin{array}{l}-2.079 \\
(0.038)\end{array}$ & $\begin{array}{l}-1.71 \\
(0.087)\end{array}$ & $\begin{array}{l}5.931 \\
(0.000)\end{array}$ & $\begin{array}{l}-2.763 \\
(0.006)\end{array}$ & $\begin{array}{l}-0.9 \\
(0.368)\end{array}$ \\
\hline $\begin{array}{l}\text { Perishable } \\
\text { resources }\end{array}$ & $<0.01$ & $\begin{array}{l}-2.025 \\
(0.043)\end{array}$ & $\begin{array}{l}-2.265 \\
(0.024)\end{array}$ & $\begin{array}{l}7.187 \\
(0.000)\end{array}$ & $\begin{array}{l}-3.632 \\
(0.000)\end{array}$ & $\begin{array}{l}-0.876 \\
(0.381)\end{array}$ \\
\hline Low wages & $<0.01$ & $\begin{array}{l}-11.832 \\
(0.000)\end{array}$ & $\begin{array}{l}2.079 \\
(0.038)\end{array}$ & $\begin{array}{l}3.333 \\
(0.001)\end{array}$ & $\begin{array}{l}3.333 \\
(0.001)\end{array}$ & $\begin{array}{l}0.804 \\
(0.421)\end{array}$ \\
\hline Unemployment & $<0.01$ & $\begin{array}{l}-3.407 \\
(0.001)\end{array}$ & $\begin{array}{l}-2.373 \\
(0.018)\end{array}$ & $\begin{array}{l}-0.087 \\
(0.931)\end{array}$ & $\begin{array}{l}3.684 \\
(0.000)\end{array}$ & $\begin{array}{l}2.411 \\
(0.016)\end{array}$ \\
\hline $\begin{array}{l}\text { Income per- } \\
\text { spectives }\end{array}$ & $<0.01$ & $\begin{array}{l}7.706 \\
(0.000)\end{array}$ & $\begin{array}{l}-2.204 \\
(0.028)\end{array}$ & $\begin{array}{l}-0.526 \\
(0.599)\end{array}$ & $\begin{array}{l}-3.032 \\
(0.002)\end{array}$ & $\begin{array}{l}-0.852 \\
(0.394)\end{array}$ \\
\hline $\begin{array}{l}\text { Returning } \\
\text { qualified } \\
\text { labor }\end{array}$ & $<0.01$ & $\begin{array}{l}-2.800 \\
(0.005)\end{array}$ & $\begin{array}{l}-2.600 \\
(0.009)\end{array}$ & $\begin{array}{l}-5.000 \\
(0.000)\end{array}$ & $\begin{array}{l}9.600 \\
(0.000)\end{array}$ & $\begin{array}{l}-1.200 \\
(0.230)\end{array}$ \\
\hline $\begin{array}{l}\text { Local de- } \\
\text { mand }\end{array}$ & $<0.01$ & $\begin{array}{l}5.109 \\
(0.000)\end{array}$ & $\begin{array}{l}1.596 \\
(0.110)\end{array}$ & $\begin{array}{l}1.622 \\
(0.105)\end{array}$ & $\begin{array}{l}-5.923 \\
(0.000)\end{array}$ & $\begin{array}{l}-1.862 \\
(0.063)\end{array}$ \\
\hline $\begin{array}{l}\text { Qualified } \\
\text { production }\end{array}$ & $<0.01$ & $\begin{array}{l}-2.397 \\
(0.017)\end{array}$ & $\begin{array}{l}-0.993 \\
(0.321)\end{array}$ & $\begin{array}{l}6.299 \\
(0.000)\end{array}$ & $\begin{array}{l}-3.416 \\
(0.001)\end{array}$ & $\begin{array}{c}-1.037 \\
(0.300)\end{array}$ \\
\hline
\end{tabular}

a surprise, since our study focuses on the emergence of specialization in economically lagging villages. It seems logical that low wages are a strong precondition for the development in such regions. Besides this, the preconditions are quite different for the various types of initializing processes.

Tourism-related common promotion These cases are characterized especially by local demand (given in $100 \%$ of the cases), provided by the visiting tourists, and access to local resources (given in $100 \%$ of the cases): the tourist attraction. This is not surprising, since the attractiveness of the locations makes the development of tourism-related businesses possible. According to the ISIPO reports, local people, recognizing the available opportunity, rented their houses to visitors and provided food services to them. The offered services are themselves not attracting visitors and, thus, rely on the local characters that make the location attractive and generates the opportunities.

A third specific precondition is a possibility of higher income in the district activity (given in $73.7 \%$ of the cases). The tourism industry offers higher income than the other activities. Hence, tourism businesses are founded due to their attractiveness and not due to unemployment, as is the case with some other types of initializing 
processes. This also explains why low wages are of lower importance. It only seems to be necessary for the development of a tourist-related specialization that there is not already another industry with above-average incomes present.

Needs-based common promotion This type has, besides low wages that are present also in the following three types of districts, one specific precondition: craft skills. In these cases, the population had already developed certain skills in the production of a specific good due to the specific needs in the area. This seems not to be a necessary precondition (only present in $69.6 \%$ of the cases), but seems to be an advantageous starting point for the development of respective economic specialization.

Endowment-based common promotion The identified specific preconditions for this type clearly show that local resources are the main asset that leads to the emergence of economic specialization. Furthermore, besides low wages and informal economics - which are present in almost all cases-, a very frequently present precondition is craft skills ( $78.7 \%$ of the cases). Similar to the case of needs-based promotion, there is a historical background in producing the good. However, in the case of endowment-based common promotion, this background results from the endowment of the location in the form of local resources (present in 100\% of the cases) and high-quality local material (present in $42.6 \%$ of the cases). Many of these cases are active in the field of agricultural products, which can be seen in the comparable very high relevance of the precondition "perishable goods", meaning that perishable goods are often processed on the spot (46.8\% of the cases).

Local innovative entrepreneur The preconditions for this type differ strongly from those above. Besides low wages, there are two specific preconditions: unemployment and returning qualified labor. The founding of a crucial firm as the initializing process for the emergence of a specialized region is also frequently found in the literature (Brenner and Mühlig 2013). In the cases studied here, the founder of this first business has in most cases (76.6\% of the cases) left the region and collected know-how elsewhere before he returned to the region and started the business. This is probably owing to the fact that the region itself is economically lagging and does not offer the required know-how. The precondition of high unemployment seems to foster the development because this causes the local population to join as workers or to found their own business. Nevertheless, this seems not to be a necessary precondition, since it is found only in $55.3 \%$ of the cases.

Outside investor This initializing process is rare in our sample. As a consequence, the Post-Hoc test finds a significant strong precondition only for unemployment. Indeed, in all cases of this type, unemployment is present. We can conclude that investors from outside pick such locations for their business. The same holds for low land costs, which is also given in $100 \%$ of the cases. Hence, a way to foster economic development in a lagging region is to offer low-priced conditions (wages and land prices) for outside investors. However, given the low number of this type 
of process in our sample, a successful story of this kind seems to be rather a rare event.

\section{Industry perspective}

The final aim is to analyze what kind of industries are potential candidates for specialization in small, lagging rural areas. Furthermore, we check how the different industries are related to the five identified initializing processes. Two steps are taken: First, we use the common industry classification (NACE) and identify the industries involved in our 140 analyzed cases. Second, we check statistically on a quite aggregated level, whether these industry groups are related to the kinds of initializing processes. Third, we examine for a number of 2-digit industries various general industry characteristics and their relation to the type of initializing processes.

Table 4 shows the involved industries. As expected, the involved industries are mainly low-tech. Furthermore, they mainly belong to the manufacturing sector. The

Table 4 Involved industries and their relation to the types of initializing processes (Post-Hoc test adjustment residual $\mathrm{Z}$; $p$-value in bracket)

\begin{tabular}{|c|c|c|c|c|c|c|c|}
\hline Industry & $\begin{array}{l}\text { Number } \\
\text { of } \\
\text { cases }\end{array}$ & $\begin{array}{l}\text { Pearson } \\
\text { Chi- } \\
\text { square }\end{array}$ & $\begin{array}{l}\text { Tourism- } \\
\text { related } \\
\text { common } \\
\text { promo- } \\
\text { tion }\end{array}$ & $\begin{array}{l}\text { Needs- } \\
\text { based } \\
\text { common } \\
\text { promo- } \\
\text { tion }\end{array}$ & $\begin{array}{l}\text { Endowment- } \\
\text { based } \\
\text { common } \\
\text { promo- } \\
\text { tion }\end{array}$ & $\begin{array}{l}\text { Local in- } \\
\text { novative } \\
\text { en- } \\
\text { trepreneur }\end{array}$ & $\begin{array}{l}\text { Outside } \\
\text { in- } \\
\text { vestor }\end{array}$ \\
\hline $\begin{array}{l}\text { A: Agriculture, } \\
\text { forestry and } \\
\text { fishing }\end{array}$ & 9 & 0.001 & $\begin{array}{l}-1.229 \\
(0.219)\end{array}$ & $\begin{array}{l}-1.375 \\
(0.169)\end{array}$ & $\begin{array}{l}4.363 \\
(0.000)\end{array}$ & $\begin{array}{l}-2.205 \\
(0.027)\end{array}$ & $\begin{array}{l}-0.532 \\
(0.595)\end{array}$ \\
\hline $\begin{array}{l}\text { CA: Food pro- } \\
\text { duction, bev- } \\
\text { erages and } \\
\text { tobacco }\end{array}$ & 17 & 0.000 & $\begin{array}{l}-1.743 \\
(0.081)\end{array}$ & $\begin{array}{l}-1.950 \\
(0.051)\end{array}$ & $\begin{array}{l}5.092 \\
(0.000)\end{array}$ & $\begin{array}{l}-2.031 \\
(0.042)\end{array}$ & $\begin{array}{l}-0.754 \\
(0.451)\end{array}$ \\
\hline $\begin{array}{l}\text { CB: Textiles, } \\
\text { apparel and } \\
\text { leather }\end{array}$ & 63 & 0.000 & $\begin{array}{l}-4.241 \\
(0.000)\end{array}$ & $\begin{array}{l}2.590 \\
(0.010)\end{array}$ & $\begin{array}{l}0.666 \\
(0.505)\end{array}$ & $\begin{array}{l}-0.054 \\
(0.957)\end{array}$ & $\begin{array}{l}1.224 \\
(0.221)\end{array}$ \\
\hline $\begin{array}{l}\text { CC: Wood and } \\
\text { paper products }\end{array}$ & 2 & - & - & - & - & - & - \\
\hline $\begin{array}{l}\text { CG: Rubber, } \\
\text { plastics and } \\
\text { other non- } \\
\text { metallic mineral } \\
\text { products }\end{array}$ & 7 & 0.038 & $\begin{array}{l}-1.076 \\
(0.282)\end{array}$ & $\begin{array}{l}1.936 \\
(0.053)\end{array}$ & $\begin{array}{l}-1.930 \\
(0.054)\end{array}$ & $\begin{array}{l}0.534 \\
(0.593)\end{array}$ & $\begin{array}{l}1.862 \\
(0.063)\end{array}$ \\
\hline $\begin{array}{l}\mathrm{CH} \text { : Basic } \\
\text { metals and } \\
\text { fabricated metal } \\
\text { products }\end{array}$ & 6 & 0.012 & $\begin{array}{l}-0.992 \\
(0.321)\end{array}$ & $\begin{array}{l}3.395 \\
(0.001)\end{array}$ & $\begin{array}{l}-1.780 \\
(0.075)\end{array}$ & $\begin{array}{l}-0.013 \\
(0.990)\end{array}$ & $\begin{array}{l}-0.429 \\
(0.668)\end{array}$ \\
\hline CM: Furniture & 17 & 0.000 & $\begin{array}{l}-1.743 \\
(0.081)\end{array}$ & $\begin{array}{l}-1.950 \\
(0.051)\end{array}$ & $\begin{array}{l}-3.127 \\
(0.002)\end{array}$ & $\begin{array}{l}6.188 \\
(0.000)\end{array}$ & $\begin{array}{c}-0.754 \\
(0.451)\end{array}$ \\
\hline $\begin{array}{l}\text { I: Accommo- } \\
\text { dation and food } \\
\text { service }\end{array}$ & 19 & 0.000 & $\begin{array}{l}11.832 \\
(0.000)\end{array}$ & $\begin{array}{l}-2.079 \\
(0.038)\end{array}$ & $\begin{array}{l}-3.333 \\
(0.001)\end{array}$ & $\begin{array}{l}-3.333 \\
(0.001)\end{array}$ & $\begin{array}{c}-0.804 \\
(0.421)\end{array}$ \\
\hline
\end{tabular}




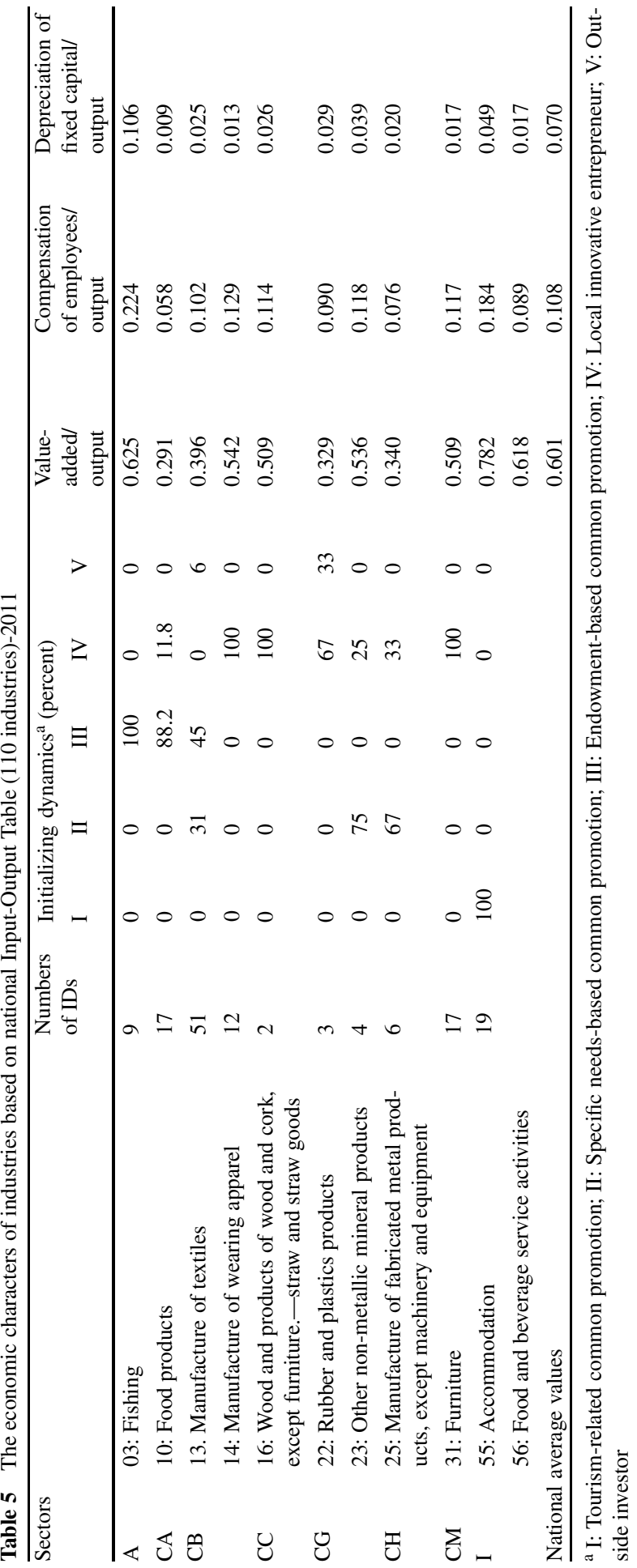


most frequent industries are textiles, apparel and leather, furniture, accommodation and food service, and food production. Considering the five types of initializing processes, it is not surprising that tourism-related common promotion dynamics are found in the accommodation and foodservice industry. Also, in line with expectations, endowment-based common promotion dynamics are found in agriculture and food production. Interestingly, specific need-based common promotion is more common in textiles, apparel, and leather as well as in the basic metals and fabricated metal products industries. Local needs and, hence, pre-experience in manufacturing products seems to be a precondition for the development of specialization in these industries. Another interesting finding is that specialization in the furniture industry is mainly based on local innovative entrepreneurs. This means that local endowment and needs do not play an important role in this industry, and the emergence of specialization is rather caused by economic incentives. Outside investors are rare so that no significant conclusions can be drawn.

Table 5 shows some economic indicators for the involved industries, pointing to some interesting aspects. First, tourism-related industries show higher value-added per output and, in the case of accommodation, also higher compensation for employees. This corresponds to the above finding that higher income is a strong incentive for entrepreneurs in this industry. The tourism sector seems to be an adequate industry to increase income in rural lagging places and trigger economic development. Second, the characteristics of the two main industries connected to endowmentbased initializing processes, fishing and food products, are quite different. Industry characteristics seem not to matter for these processes, but the availability of specific endowments. Third, industries connected with need-based initial dynamics show for all three characteristics - value-added, compensation of employees, and depreciation of capital-values slightly or clearly below average (with the slight exception of compensation of employees in manufacturing of mineral products). These kinds of specializations focus on economic activities that are not attractive (with respect to economic value creation) on the national level but attractive for the region. Fourth, local innovative entrepreneurs are especially relevant in industries with very low depreciation of fixed capital. This might be caused by the fact that entrepreneurs in not developed areas are not able to finance high capital depreciation. The same seems to hold for investors from outside the region, although the cause might be different and the number of observations is small so that this should not be overinterpreted.

\section{Conclusions}

The central aim of this paper is to investigate the relationship between initializing processes and preconditions in the emergence of specialization in rural (lagging) small-scale locations of Iran. To this end, 140 specialized villages are comprehensively studied. We identify five different initializing processes that are relevant: tourism-related common promotion, specific need-based common promotion, endowment-based common promotion, local innovative entrepreneurs, and outside in- 
vestors. For each of them, the relevant preconditions and the involved industries are examined.

This helps to understand how specialization emerges in lagging rural areas. The first policy conclusion is that there are different development strategies for regions, reflecting the five different initializing processes. It is shown that different preconditions are central to different developments, and strategies should be based on the given preconditions in a location. One option is based on the local endowment, either in the form of tourism-relevant factors (tourism-related dynamics) or in form of resources and developed skills in their processing (endowment-based dynamics, mainly in the agricultural sector and food processing, but also in textiles) or in form of production skills that have been developed in the past for various reasons (needsbased dynamics). All these developments require certain preconditions so that they cannot be applied to all locations. Hence, policymakers might look for such specific endowments and production skills and support respective developments. This is a place-based strategy, which might be seen as a smart specialization strategy for less developed regions, but requires the existence of specific circumstances or skills. Furthermore, it requires entrepreneurial skills and the willingness and resources to start a business on the part of local people. The government might invest in respective education and support in economically lagging rural areas.

Another option is the foundation of an initial firm in the region, which functions as a role model that others follow. This can either be done by a local person or an investor from outside. The latter seems to be rare. The former seems more likely in places with high unemployment and is usually done by people returning to the region after collecting relevant experiences outside. This seems an important mechanism for lagging regions that miss specific endowments, which could be supported by policy measures.

To sum up, according to our findings, there are two basic ways for developing economic specialization and progress in lagging regions: Specific endowments and pre-developments, if available, can be used as a starting point or people from the region that have gained qualifications outside can return to the region.

In conducting this research, we have encountered limitations that need to be addressed. The present study was based on the reports of ISIPO. The advantage of using the reports is that the information is given in a somewhat standard form. The limitation is that the people conducting the reports gathered mainly qualitative information via interviews, and that their interpretations of the situations might be subjectively biased. Therefore, identically structured field studies, including in-depth interviews and questionnaire design could further improve the understanding of the emergence of economic specialization in lagging regions. Moreover, we have also encountered limitations in estimating the impact of each factor statistically due to the number of cases. Further research should complement the results, possibly modifying and supplementing our findings. Results for other countries would be especially interesting. Nevertheless, extending the analysis to more developed regions or more urban regions would also broaden the understanding.

However, we expect that our results can be transferred to other economically lagging regions, especially in rural areas of developing countries. Case studies of regions in other countries show that similar processes occur there (e.g., Mottaleb and 
Sonobe 2013; Voronkova et al. 2019). Of course, a similar study in such countries would be necessary to confirm this expectation. We find the strong importance of local preconditions that is in line with the literature on path-dependence and the related policy discussion (Barca 2019; Barca et al. 2012; Rodrik 2005). Hence, our study supports the argument that spatially-blind development strategies are undermined by institutional and cultural problems, while placed-based policies are better suited and more likely to increase local and national growth (Farole et al. 2011), especially by raising the potential for development in remote areas (Garcilazo et al. 2010).

While we believe that our results can be transferred to other rural areas in developing countries, this might only partly be the case in other areas. One specificity in our cases is that the locations are small and no other relevant economic development existed during the period of time studied. Impacts on other economic developments in the region play no role, but they are an issue in regions with further relevant economic activities as well as in later developments in our regions. We focused on the very early developments of the first specializations in the regions. Further studies should also look at later developments and the interactions between specializations (see, e.g., Breul et al. 2021).

Our study also detects a number of further issues that should be addressed in future studies: 1) Why do not all regions that have a common perception of available resources develop a successful economic specialization? 2) How could policy trigger such a development? 3) How can policy measures trigger reverse immigration of people that obtained skills and education outside the region and might trigger economic development? 4) Is the emergence of economic specialization based on low wages an adequate aim, and how can policy support the bargaining power of producers and workers in the region so that they obtain a larger share of the added value in the value chain? 5) How can investors be attracted to lagging rural areas and what role can (corporate) venture capital firms play in this context?

\section{Appendix}

\subsection{Appendix I: Questions answered in the reports}

In the following we list the questions and sub-questions that have to be answered in each of the ISIPO reports:

\subsubsection{Question 1}

- 1.1 Focus of the business cluster

- 1.2 Estimated number of cluster firms

- 1.3 Trends during the last 5-10 years (in terms of sales, production, innovation, number of units, employment, etc.)

- 1.4 Forecast for the next 5 years (in terms of sales, production, innovation, number of units, employment, etc.) 
- 1.5 Weaknesses and strengths, threats and opportunities

- 1.6 Main proposed solutions to improve the condition of the cluster

- 1.7 Main argument for supporting the cluster

- 1.8 Which of the following factors does the cluster mainly rely on: human resources, technology or other items?

\subsubsection{Question 2}

- 2.1 Name of final product or service

- 2.2 Names of intermediary products

- 2.3 Geographical location

- 2.4 Production type (artisan, traditional, industrial, service)

- 2.5 History of cluster (how did it emerge, situation during the last ten years, analysis of turning points, current conditions)

- 2.6 Number of firms (in firm size classes (self-employed, micro, small, medium, large (>150 employees)) and separate into industrial and artisan)

\subsubsection{Question 3}

- 3.1 Number of cluster firms

- 3.2 Number of units producing raw materials and ancillary materials

- 3.3 Number of machine-building enterprises

- 3.4 Number of firms supplying raw materials and ancillary (regional, national, international)

- 3.5 Number of firms producing final products (regional, national, international)

- 3.6 Number of firms producing intermediary products (regional, national, international)

- 3.7 Number of unions

- 3.8 Number of cooperatives

- 3.9 Number association

- 3.10 Number of consortia

- 3.11 Number of BDS

- 3.12 Number of government agencies

- 3.13 Number of research and academic institutions

- 3.14 Growth of the number of firms during the last 5 years

- 3.15 Relationships in the cluster (number of cases in the last three months separately for vertical, horizontal and diagonal relationships)

- 3.16 Stage in the cluster life-cycle (embryonic, forming, developing, developed) 


\subsubsection{Question 4}

- 4.1 Type and name of main raw materials

- 4.2 Type and name of secondary raw materials

- 4.3 Main production process

- 4.4 Source of main raw materials $(>80 \%, 50-80 \%, 20-50 \%,<20 \%$ from region (within $100 \mathrm{~km})$ )

- 4.5 Source of secondary raw materials $(>80 \%, 50-80 \%, 20-50 \%,<20 \%$ from region)

- 4.6 Trend of regional source of raw materials and inputs during the last 5-10 years (increasing, constant, decreasing)

- 4.7 Number of units supplying raw materials and inputs located in the region

- 4.8 Source of supply of equipment and machinery (percentage region, national, international)

\subsubsection{Question 5}

- 5.1 Percentage of firms with access to infrastructure facilities (water, electricity, phone, internet)

- 5.2 Distance to main road

- 5.3 Distance to main city

- 5.4 Existence of railway station within $50 \mathrm{~km}$

- 5.5 Existence of airport within $50 \mathrm{~km}$

- 5.6 Distance to the nearest related research center

- 5.7 Percentage of firms located in an industrial park

\subsubsection{Question 6}

- 6.1 Estimate of value added

- 6.2 Degree of industrialization (level of mechanization) of producing firms (high, medium, low)

- 6.3 Type of production technology (high, medium, low, artistic)

- 6.4 Level of specialization of producing firms (high, medium, low)

- 6.5 Percentage of different qualities of products (high, medium, low)

\subsubsection{Question 7}

- 7.1 Sales (separated for each product/service and for regional, national and international)

- 7.2 Main regional markets

- 7.3 Cities within Iran where the products are offered

- 7.4 Other countries where the products are offered 
- 7.5 Share of producers selling directly or through middleman to other countries

- 7.6 Share of production based on order and without orders

- 7.7 Change of total, regional, national and international sales within the last five years (increasing, constant, decreasing)

- 7.8 Expected sales in the next five years (increasing, constant, decreasing)

- 7.9 Expected exports in the next five years (increasing, constant, decreasing)

- 7.10 Existence of a Business Development Services $(B D S)$

- 7.11 Existence of a trade consortium

- 7.12 Export potentials

- 7.13 Market barriers, especially with respect to exports

- 7.14 Trend of main products for the next five years (regional, national, international)

- 7.15 Existence of a common brand

\subsubsection{Question 8}

- 8.1 Annual sales (monetary)

- 8.2 Percentage of firms that received loans within the last three years

- 8.3 Average time interval form good/service delivery until payment receipt

- 8.4 Maximum debt that firms asked form customers

- 8.5 Existence of funding or financial institution (formally or informally)

- 8.6 Existence of government incentives and support

- 8.7 Existence of advance payment for goods

\subsubsection{Question 9}

- 9.1 Number of employees in cluster (total, permanent, seasonal employment)

- 9.2 Educational composition of employment (illiterate, without Diploma, with Diploma, Bachelor degree and higher)

- 9.3 Skill composition of employment (unskilled, semi-skilled, skilled)

- 9.4 Average salary (unskilled, semi-skilled, skilled, Diploma, Bachelor degree and higher)

- 9.5 Work environment (good, medium, bad)

- 9.6 Percentage of people insured (managers and owners, workers)

- 9.7 Change of employment rate in last five years (increasing, constant, decreasing)

- 9.8 Number of designer employees

- 9.9 Total number of employees in the province

\subsubsection{Question 10}

- 10.1 Which factors does the cluster rely on? (market, infrastructure, resources and raw materials, skilled and specialized employees, others) 
- 10.2 Social issues

- 10.3 Environmental issues

- 10.4 Threats and opportunities of the cluster

\subsection{Appendix II}

Additional literature and internet pages that are used to gather information on the studied cases:

- A time with the residents of a village of Hamedan without unemployed people/Dastjerd's local people are waiting for the fulfillment of the sweet promises of the authorities. (2018, May 27). Tasnim News Agency. Retrieved by www. tasnimnews.com.

- A village that brought unemployment to its knees. (2018, November 11). Iranian students' News Agency. Retrieved by www.isna.ir.

- A village with the characteristics of a resistance economy. (2016 February 9). IRIB News Agency; Markazi provenience branch. Retrieved by http://markazi.irib.ir.

- A village without an unemployed person in Hamedan/sanctions is caused to attractiveness of "Negarkhatoon”. (2020, January 14). Fars News Agency. Retrieved by www.farsnews.ir

- Another industry downhill Promises: 120 Dehful furniture and inlay firms on the brink of closure/raw materials low. (2018, September 30). Mehr News Afency. Retrieved from https://en.mehrnews.com.

- Ashtarmal a mysterious wooden village/“One House, One firm”. (2020, May 11). Fars News Agency. Retrieved by www.farsnews.ir.

- Basket Mat Weaving rival of Lalejin pottery in export/lack of branding Hamedan handicrafts problem. (2013, June 17). Mehr News Agency. Retrieved by www. mehrnews.com.

- Chaharmahal \& Bakhtiari province. (2018. December 6). Iran Sheikh-Shaban village inlay Persian handicraft [Video]. www.youtube.com/watch?v=1uGiQZq1mj4.

- Cluster Development Agent (CDA) of bedsheet cluster in Dariche: 25\% of the country's bedsheets are produced in the country. Economic progress will be achieved through organizational sales. (2012 August 12). Iranian Students' News Agency. Retrieved from https://isna.ir.

- Deh Namak, the center of clothing and knitwear production: Deh Namak village of Arak district is the center of clothing and knitwear production in Markazi province. (2018 November 17). IRIB News Agency. Retrieved by www.iribnews. ir.

- Dehagh, the city of employees. (2017, November 27). IRIB News Agency. Retrieved from https://iribnews.ir.

- Dehnavarzaman; A village without unemployment and self-sufficient in the production of inlaid furniture. (2017, September 19). Iranian students' News Agency. Retrieved by www.isna.ir.

- Documentary of Chickpea Processors (Leblebi) Mamaqan, (2016), Sahand Tabriz TV Channel, retrieved from https://www.aparat.com. 
- evelopment of furniture and inlay industry in Hamedan province: Inlaid decorative art is one of the most beautiful and valuable handicrafts of artists in Hamedan province. (2017, May 22). IRIB News Agency. Retrieved by www.iribnews.ir.

- Formation of industrial clusters; A turning point in Mashhad furniture industry. (2017, June 1). Jamaran News Website. Retrieved from www.jamaran.news.

- Furniture makers of Markazi province, under the razor of corona and currency. (2020, August 5). Iranian Students' News Agency. Retrieved by www.isna.ir.

- Hedag, Shoe Manufacturing Center. (2020. March 1). Neghah Media. Retrieved by http://www.negahmedia.ir

- Iranian art entered the world market; The traditional Giveh of Shiraz went to Italy. (2018 August 30) IRIB News Agency, Retrieved from www.iribnews.ir.

- Isfahan Khorzoogh Cluster Development Agent: The traditional culture of clothing production must change; The need to modernize the group business culture. (2012, October 6). Iranian Students' News Agency. Retrieved from www.isna.ir.

- Kaj village, the center of the country's photo frame production. (2019, October 28). IRIB News Agency. Retrieved by www.iribnews.ir.

- Kerdabad industrial cluster in the idea of capturing the markets of the region. (2019, November 23). Sepehr-Gharb Newspaper, Retrieved from www. sepehrgharb.ir.

- Lahijan cookies, world fame, delicious memories. (2012, July 3). Iranian Student's News Agency. Retrieved by www.isna.ir.

- Mamaqan; Lebilebi World City. (2019 January 8). The Islamic Republic News Agency. Retrieved from www.irna.ir.

- Manifestation of resistance economy in Zarnosheh village: Zarnosheh, a village in Markazi province where the word unemployment has no meaning. (2018, December 24). IRIB News Agency. Retrieved by www.iribnews.ir.

- Miracle of the finger of Kermani artists; When the art of language is spoken/ from Kerman carpet to Pete. (2016, March 14). Mehr News Agency. Retrieved by ww.mehrnews.com

- Payeshgar News. (2015 May 31). Production of rubber parts for light vehicles in Mahnian village [Video]. www.aparat.com/v/aQrpV.

- Pottery, the art of the ancestors of the people of East Azerbaijan/“Kuzehkonan” pottery is nationally registered. (2012, Janusary 5) Mehr News Agency. Retrieved from www.mehrnews.com

- Prosperity of rural production and employment: Samqavar of the country's inlaid village. (2018 June 9). IRIB News Agency. Retrieved by www.iribnews.ir.

- Rural development with the growth of spontaneous industrial clusters. (2019, march 6). The Islamic Republic News Agency. Retrieved by www.irna.ir.

- Sadeghi. S; Jahangiri. J. (2012) Estimating Health Tourists' Willingness to Pay (Case of Sarein Springs' Visitors). Tourism Management Studies. 7 (18). 111-133. (Persian).

- Safaei, B; Ahmadi, M. (2012). Explaining the Effects of Factors in the Emergence of Industrial Clusters, as a Tool to Facilitate National Production; Case Study of Juibar Agricultural Equipment Industrial Cluster. The First National Conference on Strategies to Promote Management, Accounting and Industrial Engineering in Organizations (Gachsaran). https://civilica.com/doc/213502. 
- Sameii-Siss. N. (2020. July 5). Kuzekonan,the cradle of Iranian pottery [Video]. Aparat. www.aparat.com/v/AdRTw.

- Seyed Shahab; Inlaid center of the country/reverse migration to the village. (2011, December 24). Mehr News Agency. Retrieved by www.mehrnews.com.

- Sharifzadeh, M; Abdollahzadeh Gh; Divansalar, A. (2018). The role of agricultural industrial clusters in the development of rural business in Mazandaran province. Journal Space Economy \& Rural Development. 7(2). 227-247.

- Sheikh-Shaban is the jewel of inlay work in Iran. (2017, March 6). Iranian Labor News Agency. www.ilna.news.

- Shoemaker wearing (Abadeh). (2012 March 28). Fars Central Broadcasting, Retrieved from http://fars.irib.ir.

- Tasnim reporter's account of Khalkhal carpet production; firms that work only for not living hand to mouth. (2018, December 12). Tasnim news. Retrieved from www.tasnimnews.com.

- The boom in business reversed immigration: "Kerdabad" is a sample village of resistance economy/houses that have become firms. (2018 December 25). Mehr News Agency, Retrieved from www.mehrnews.com.

- The industrial area of Analujeh village in Chadegan was exploited. (2017, June 29). Islamic Republic News Agency. Retrieved from https://en.irna.ir.

- Tours in Mohammad-Abad Miami Firms, the Center of Shirt Production: We Sell Sewing Machines, We Buy Cows. (2019. August 19). Iran Online. Retrieved by http://www.ion.ir.

- Unemployment has been eradicated in this desert village: the village of woodcarvers. (2017, November 3). Jame-Jam Online. Retrieved by https://jamejamonline. ir.

- Unveiling of the world's smallest handmade knife in Neyriz/Let's not let the knife cut its handle! (2015 June 10). Dana Information Network. Retrieved by www. dana.ir.

- Zarnosheh Ashtian Industrial Village; A successful economic model. (2015, November 3). The Islamic News Agency. Retrieved by www.irna.ir.

\subsection{Appendix III}

\subsubsection{Case 1: Kani-Sanan (Common perception-tourism district)}

Kani-Sanan, in the district of Marivan, is a village located in the border areas and has a history of nearly 150 years. It is located at the foot of a mountain, at a short distance from Zarivan Lake, and lies on the travelling route from Iran to Iraq. Furthermore, the houses in the village are built with interesting architecture: ordered in a row, right behind each other and without any of them facing the view of another house. That is why it has attracted the attention of tourists. In the village, with the arrival of tourists, locals rented their houses to tourists and provided them with local food. With an emerging tourism sector, the former main occupation, agriculture, was replaced. The Koredestan province report of Cluster Map (2011), states that in the emerging phase of the cluster, people provided services reacting to the demand of tourists. 
Fig. 2 View of Kani-Sanan. (The picture Source: Islamic Republic News Agency. Retrieved from https://en.irna.ir)

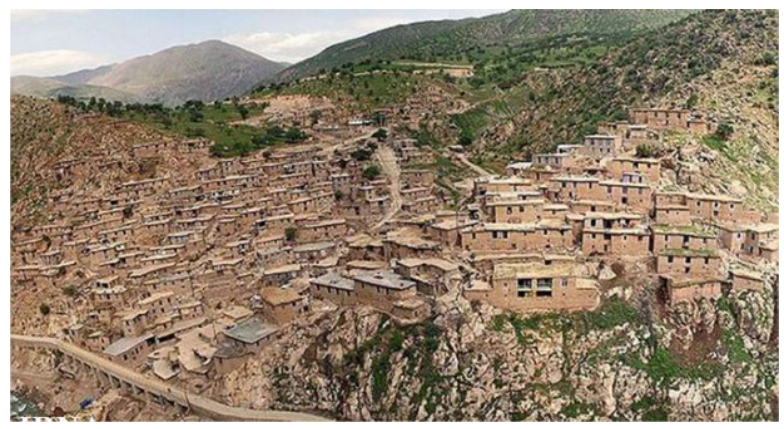

Although tourism infrastructure and skilled labor are not highly given in the region, the number of tourists is high due to the natural, geographical and cultural reasons mentioned above. Banking facilities are also not easily available. Most of the firms are micro running their business with the members of the family. It is worth noting that the sense of hospitality is also high among local people.

\subsubsection{Case 2: Abadeh (Common perception-needs-based district)}

Businesses in this district produce light, durable summer footwear (Giveh) that is adequate for long walks. The products are sold, especially to villagers and nomads in mountainous and arid regions (e.g., provinces of Fars, Chaharmahal and Bakhtiari, Kermanshah, and Kurdistan). The products are specifically designed for the regional conditions, characterized by the existence of impassable crossings, lack of car roads, livestock, and agriculture-based livelihood. In response to the specific needs, people in nomadic, rural, and semi-urban areas have started to produce goods with the material available in the area. Thus, more than $80 \%$ of the raw materials are provided from within the region. Abadeh was the place in which Giveh of the highest quality was produced. Hence, it was very competitive also in markets outside the region. Consequently, local people, due to the favorable income conditions in the production
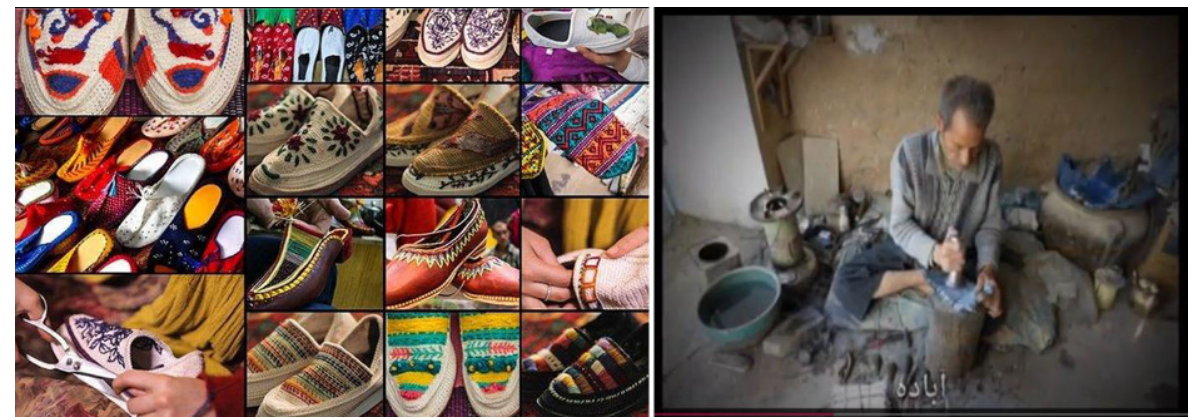

Fig. 3 View of production and products in Abadeh. (Resource: Iranian art entered the world market; The traditional Giveh of Shiraz went to Italy. (2018 August 30) IRIB News Agency, Retrieved from www.iribnews.ir. Shoemaker wearing (Abadeh). (2012 March 28). Fars Central Broadcasting, Retrieved from http://fars.irib.ir) 

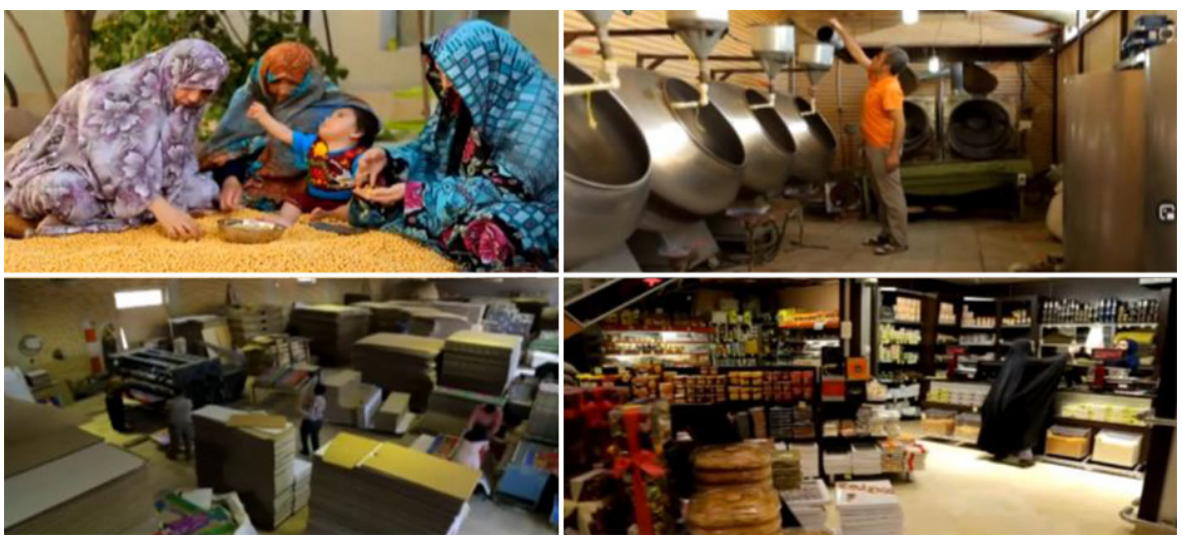

Fig. 4 Production in Mamagan. (Resource: Documentary of Chickpea Processors (Leblebi) Mamaqan, (2016), Sahand Tabriz TV Channel, retrieved from https://www.aparat.com)

of Giveh, turned from agriculture to the production of this commodity and started to export them. It is worth mentioning that since the organic yarn and leather made by the villagers themselves are used in making Giveh, the product is also sold in European markets.

\subsubsection{Case 3: Mamaqan (Common perception-endowment-based district)}

Mamaqan is climatically suitable for the production of quality chickpeas, causing most people to be traditionally engaged in agriculture. From this, it moved to become a cluster in the production of Leblebi, a snack made from roasted chickpeas. Formally, the first cluster firms emerged in the 1960s, when many people in the region, having roughly the same assets (raw materials, the possibility of production at home, and the common know-how to produce Leblebi) reacted to the situation similarly: starting small home-based businesses known as "one house, one firm". In the following, the development of the Leblebi production was such that the chickpeas harvested even in the whole East Azerbaijan province do not meet the required amount. This has led to the import of chickpeas from more than 15 other provinces. It is worth mentioning that there is no other region in Iran able to compete with this industrial district so that it operates as a monopolist in the market. 1300 firms belong to this industry in the city in 2015 .

\subsubsection{Case 4: Kerdabad (entrepreneur-based district)}

Base on the feasibility report of the Kerdabad industrial cluster (2013), in the late 1990s, due to drought and natural disasters, people from this village were unable to continue their agricultural occupation and migrated to large cities, especially Tehran. In Tehran, given their still intact social ties from the village, those working in the clothing sector helped others to find a job in this sector. Consequently, most of them either worked in sewing firms or as apprentices in other firms producing or distributing clothes and apparel. They became experienced in sewing, designing, 


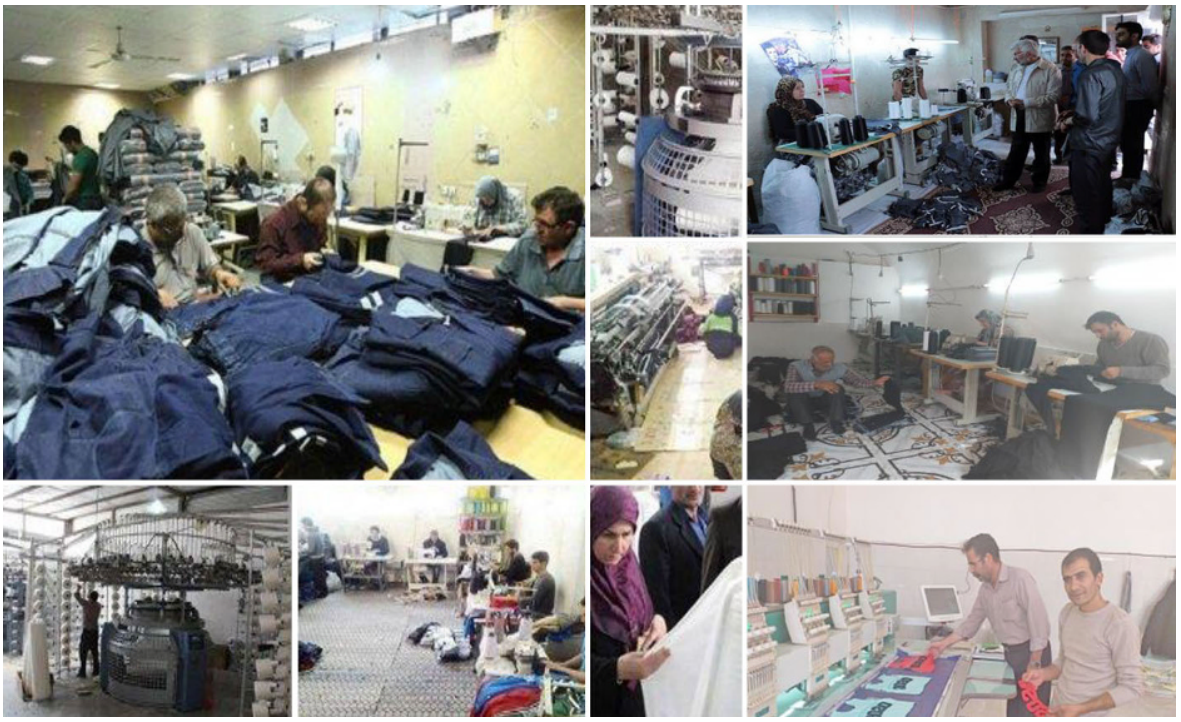

Fig. 5 View of firms in Kerdabad. (Resource: Mehr News Agency, retrieved from www.mehrnews.com; Sepehr-Gharb Newspaper, Retrieved from www.sepehrgharb.ir)

printing and cutting fabrics, weaving, and even using various machines, and some of them established a firm around Tehran alone or in partnership. However, these firms faced problems, such as the inability to independently purchase fabrics and raw materials, high rents, miscellaneous expenses such as taxes, family expenses, and being away from family. These factors led to the establishment of a business in Kerdabad village in 2003. In the beginning, there was a problem with the lack of trust by principals and customers in Tehran who provided fabrics and raw materials and distribute and sell the clothes. Once these problems have been solved, the workers in Tehran realized that they could own a firm in the village at low costs and with the help of their family (they often turned their houses into firms). The return process of those who were skilled in various fields of clothing continued. Gradually, related firms were created with different specializations.

The village is now booming, and its population has increased in recent years. The region even faces a shortage of employees and needs to attract labor force from the surrounding regions. However, attracting workers from the surrounding is limited due to the lack of transportation services and facilities, still low wages, and a lack of skilled employers. This caused the development to stop.

800 people work in 200 clothing firms in Kerdabad. The emergence of this industrial district was based on a returning skilled workforce, but was weak in terms of the existence of people specialized in marketing and sales. Furthermore, over $80 \%$ of the raw materials are supplied from outside the region, mostly by the customers. 


\subsubsection{Case 5: Sistan (Investor district)}

The report in "Cluster map" of Fars providence (2011) states that in the rural areas of Sistan only scattered production of carpets existed before 1968, based on access to raw materials. Due to the great drought in 1968, the region faced severe problems in agricultural and livestock activities, which had been the main occupation of the people and the supply of raw materials for carpet production (second occupation). High unemployment resulted, and the Iran Carpet Company helped the people by investing in the region. Other companies followed their example, establishing a carpet industry in the region based on two business concepts:

1. Carpet weaving subsidiaries: These regional subsidiaries are led and managed from Tehran. Raw materials are preprocessed in Tehran or even abroad and sent to subsidiaries by the companies. The produced carpets are sent to Tehran and exported from there.

2. Rural carpet production: In this case production takes place in rural houses. Raw materials are provided by the producers themselves or bought on the market. They spin the wool themselves and give it to dyers in the city or buy dyed wool on the market. Rural carpets are woven without images or with simple and large shapes and are sold within the city or in the surrounding cities.

The report states that this industrial region relies on local human resources (which were often trained by investment companies) and market access (provided by investment companies). Less than $50 \%$ of the raw materials originate from the region.

\subsection{Appendix IV}

Table 6 Information on the interviews with CDAs

\begin{tabular}{llllll}
\hline Subject & $\begin{array}{l}\text { The num- } \\
\text { ber of } \\
\text { intervie- } \\
\text { wees }\end{array}$ & $\begin{array}{l}\text { The } \\
\text { number } \\
\text { of cases }\end{array}$ & $\begin{array}{l}\text { Time } \\
\text { frame }\end{array}$ & $\begin{array}{l}\text { Date } \\
\text { of con- } \\
\text { duction }\end{array}$ & Main content \\
\hline $\begin{array}{l}\text { Filling missing } \\
\text { data }\end{array}$ & 4 & 9 & $\begin{array}{l}10-15 \mathrm{~min} \\
\text { for every } \\
\text { village }\end{array}$ & $\begin{array}{l}\text { 5-10 } \\
\text { April } \\
2019\end{array}$ & $\begin{array}{l}\text { Details on the history of } \\
\text { the villages } \\
\text { Relevance of the factors } \\
\text { for the cluster emergence }\end{array}$ \\
$\begin{array}{l}\text { Discussion of } \\
\text { classification of } \\
\begin{array}{l}\text { industrial district } \\
\text { types }\end{array}\end{array}$ & 4 & $20-30$ min & $\begin{array}{l}20-26 \\
\text { April } \\
\text { Collecting views on the } \\
\text { different developments }\end{array}$ \\
\hline
\end{tabular}




\subsection{Appendix V}

Table 7 Share of the types of industrial district with each of the preconditions

\begin{tabular}{|c|c|c|c|c|c|c|c|}
\hline & $\begin{array}{l}\text { Precondi- } \\
\text { tions }\end{array}$ & $\begin{array}{l}\text { Tourism } \\
\text { district }\end{array}$ & $\begin{array}{l}\text { Endowment- } \\
\text { based } \\
\text { district }\end{array}$ & $\begin{array}{l}\text { Needs- } \\
\text { based } \\
\text { district }\end{array}$ & $\begin{array}{l}\text { Investor } \\
\text { district }\end{array}$ & $\begin{array}{l}\text { Entrepre- } \\
\text { neur-based } \\
\text { district }\end{array}$ & $\begin{array}{l}\text { Total } \\
(\%)\end{array}$ \\
\hline 1 & Family & 100 & 100 & 100 & 100 & 97.826 & 99.281 \\
\hline 2 & $\begin{array}{l}\text { Informal } \\
\text { economics }\end{array}$ & $100 *$ & $100 *$ & 73.913 & 75.000 & 78.723 & 87.857 \\
\hline 3 & Wages & 0.000 & $100 *$ & $100^{*}$ & $100 *$ & $100^{*}$ & 86.429 \\
\hline 4 & $\begin{array}{l}\text { Local } \\
\text { resources }\end{array}$ & $100^{*}$ & $100 *$ & 69.565 & 0.000 & 31.915 & 69.286 \\
\hline 5 & Land prices & 73.684 & 61.702 & 69.565 & 100 & 72.340 & 69.286 \\
\hline 6 & $\begin{array}{l}\text { Local } \\
\text { market }\end{array}$ & $100^{*}$ & 55.319 & 60.870 & 0.000 & 10.638 & 45.714 \\
\hline 7 & $\begin{array}{l}\text { Former } \\
\text { production } \\
\text { ability }\end{array}$ & 0.000 & $78.723 *$ & $69.565^{*}$ & 25.000 & 0.000 & 38.571 \\
\hline 8 & $\begin{array}{l}\text { Unemploy- } \\
\text { ment }\end{array}$ & 0.00 & 34.000 & 13.000 & $100^{*}$ & $55.300^{*}$ & 34.500 \\
\hline 9 & $\begin{array}{l}\text { Qualified } \\
\text { returning } \\
\text { labor }\end{array}$ & 0.000 & 0.000 & 4.348 & 0.000 & $76.596^{*}$ & 26.429 \\
\hline 10 & $\begin{array}{l}\text { Qualified } \\
\text { production }\end{array}$ & 0.000 & $51.064 *$ & 13.043 & 0.000 & 4.255 & 20.714 \\
\hline 11 & $\begin{array}{l}\text { High qual- } \\
\text { ity local } \\
\text { material }\end{array}$ & 0.000 & $42.553 *$ & 4.348 & 0.000 & 4.255 & 16.429 \\
\hline 12 & $\begin{array}{l}\text { Perishable } \\
\text { resources }\end{array}$ & 0.000 & $46.800 *$ & 0.000 & 0.000 & 0.000 & 15.700 \\
\hline 13 & Income & $73.684^{*}$ & 12.766 & 0.000 & 0.000 & 2.128 & 15.000 \\
\hline 14 & $\begin{array}{l}\text { Center } \\
\text { closeness }\end{array}$ & 0.000 & 8.511 & 0.000 & 0.000 & 10.638 & 6.429 \\
\hline 15 & $\begin{array}{l}\text { Policy } \\
\text { support }\end{array}$ & 0.000 & 2.128 & 4.348 & 0.000 & 8.511 & 4.286 \\
\hline 16 & $\begin{array}{l}\text { Price fluc- } \\
\text { tuation }\end{array}$ & 0.000 & 8.511 & 0.000 & 0.000 & 0.000 & 2.857 \\
\hline \multicolumn{2}{|c|}{ Total Number } & 19 & 47 & 23 & 4 & 47 & 140 \\
\hline
\end{tabular}

*In the significant level of $\% 5$ the case is different comparing with others type and more frequently present 
Funding Open Access funding enabled and organized by Projekt DEAL.

Open Access This article is licensed under a Creative Commons Attribution 4.0 International License, which permits use, sharing, adaptation, distribution and reproduction in any medium or format, as long as you give appropriate credit to the original author(s) and the source, provide a link to the Creative Commons licence, and indicate if changes were made. The images or other third party material in this article are included in the article's Creative Commons licence, unless indicated otherwise in a credit line to the material. If material is not included in the article's Creative Commons licence and your intended use is not permitted by statutory regulation or exceeds the permitted use, you will need to obtain permission directly from the copyright holder. To view a copy of this licence, visit http://creativecommons.org/licenses/by/4.0/.

\section{References}

Akoten JE, Sawada Y, Otsuka K (2006) The determinants of credit access and its impacts on micro and small enterprises: The case of garment producers in Kenya. Econ Dev Cult Change 54(4):927-944

Anh NT (2013) One village one product (OVOP) in Japan to one tambon one product (OTOP) in Thailand: Lessons for grass root development in developing countries. J Soc Dev Sci 4(12):529-537

Barca F (2019) Place-based policy and politics. Renewal 27(1):84-95

Barca F, McCann P, Rodríguez-Pose A (2012) The case for regional development intervention: place-based versus place-neutral approaches. J Regional Sci 52(1):134-152

Barzotto M, Corradini C, Fai F, Labory S, Tomlinson PR (2020) Smart specialisation, Industry 4.0 and lagging regions: some directions for policy. Reg Stud Reg Sci 7(1):318-332

Bathelt H, Boggs JS (2003) Toward a reconceptualization of regional development paths: is Leipzig's media cluster a continuation of or a rupture with the past? Econ Geog 79(3):265-293

Bathelt H, Conserva N (2018) Globalization and industrial change in Italian industrial districts. In: Glückler J et al (ed) Knowledge and institutions. Knowledge and Space, vol 13, pp 247-269

Beasley TM, Schumacker RE (1995) Multiple regression approach to analyzing contingency tables: post hoc and planned comparison procedures. J Exp Educ 64(1):79-93

Becattini G (1990) The Marshallian industrial district as a socio-economic notion. In: Industrial districts and inter-firm co-operation in Italy, pp 37-51

Belussi F (2015) The international resilience of Italian industrial districts/clusters (ID/C) between knowledge re-shoring and manufacturing off (near)-shoring. Investigaciones Regionales 32(August):89-113

Belussi F, Sedita SR (2009) Life cycle vs. multiple path dependency in industrial districts. Eur Plan Stud 17(4):505-528

Benner M (2009) What do we know about clusters? In: Search of effective cluster policies

Boschma R (1996) The window of locational opportunity-concept (No. 260). Quaderni-Working Paper DSE

Brautigam D (1997) Substituting for the state: Institutions and industrial development in Eastern Nigeria. World Dev 25(7):1063-1080

Brenner T (2004) Local industrial clusters: existence, emergence, and evolution. Routledge, London

Brenner T, Mühlig A (2013) Factors and mechanisms causing the emergence of local industrial clusters: a summary of 159 cases. Reg Stud 47(4):480-507

Breul M, Hulke C, Kalvelage L (2021) Path formation and reformation: studying the variegated consequences of path creation for regional development. Econ Geog 97(3):213-234

Brusco S, Malagoli W (1981) Disintegrated firms and industrial districts: the case of knitwear industry in Italy, studio presentato al. In: Third conference of the international Working Party on Labour Market Segmentation

Canello J, Pavone P (2016) Mapping the multifaceted patterns of industrial districts: a new empirical procedure with application to Italian data. Reg Stud 50(8):1374-1387

Cappellaro F, Cutaia L, Margareci G, Scalbi S, Sposato P, Segreto MA, Valpreda E (2020) The role of collaborative and integrated approach towards a smart sustainable district: the real case of Roveri industrial district. In: Salomone R, Cecchin A, Deutz P, Raggi A, Cutaia L (eds) Industrial Symbiosis for the Circular Economy. Springer, Cham, pp 135-148

Chidumu JI (2007) The impact of "one village one product (Ovop)" on household income-implications on food security: the case of Bvumbwe operation area, Thyolo district, Malawi. Master's thesis, Egerton University, Kenya. Retrieved from https://ageconsearch.umn.edu/record/93993 
Christiaensen L, Pan L, Wang S (2013) Pathways out of poverty in lagging regions: evidence from rural western China. Agric Econ 44(1):25-44

Das K (2011) Indian rural clusters and innovation: challenges for inclusion. Econ Manag Financial Mark 6(1):283-301

Denpaiboon C, Amatasawatdee C (2012) Similarity and difference of one village one product (OVOP) for rural development strategy in Japan and Thailand. Japanese Stud J Special Issue: Regional Cooperation for Sustainable Future in Asia. 52-62

Deputy of Small Industries of Iran Small Industries and Industrial parks organization (ISIPO) (2016) The business cluster development guidelines include: Instructions, style sheets, questionnaires, service descriptions, etc. Moallef, p 311

Dosi G (1982) Technological paradigms and technological trajectories: a suggested interpretation of the determinants and directions of technical change. Res Policy 11(3):147-162

Elola A, Valdaliso JM, López SM, Aranguren MJ (2012) Cluster life cycles, path dependency and regional economic development: Insights from a meta-study on Basque clusters. Eur Plan Stud 20(2):257-279

Fan CC, Scott AJ (2003) Industrial agglomeration and development: a survey of spatial economic issues in East Asia and a statistical analysis of Chinese regions. Econ Geog 79(3):295-319

Fan X, Dai S (2017) Spatial-temporal distribution characteristics of industrial heritage protection and the influencing factors in a Chinese city: a case study of the Tiexi old industrial district in Shenyang. J Herit Tour 12(3):281-295

Fan XS, Qin CL (2005) Preliminary study on the formation and evolution process of enterprise clusters in undeveloped region in china-some idea based on the investigation of enterprise clusters in rural territory in Henan province. J Econ Geogr 3: 320-323

Farole T, Rodríguez-Pose A, Storper M (2011) Cohesion policy in the European Union: growth, geography, institutions. J Common Mark Stud 49(5):1089-1111

Foray D (2014) From smart specialization to smart specialization policy. Eur J Innov Manag 17(4):492-507

Foray D (2018) Smart specialization strategies and industrial modernization in European regions-theory and practice. Cambridge J Econ 200(9):1505-1520

Fornahl D, Henn S, Menzel MP (2010) Emerging clusters: theoretical, empirical and political perspectives on the initial stage of cluster evolution. Edward Elgar Publishing

Frenken K, Boschma RA (2007) A theoretical framework for evolutionary economic geography: industrial dynamics and urban growth as a branching process. J Econ Geogr 7(5):635-649

Gaddefors J, Korsgaard S, Ingstrup MB (2020) Regional development through entrepreneural exaptation: epistemological displacement, affordances, and collective agency in rural regions. J Rural Stud 74:244-256

Gagliardi L, Percoco M (2017) The impact of European Cohesion Policy in urban and rural regions. Reg Stud 51(6):857-868

Garavaglia C (2018) Behind the emergence of clusters: spinoffs and social ties. The case of an Italian industrial district. Int J Innov Reg Dev 8(1):23-43

Garcia-Perez MA, Nunez-Anton V (2003) Cellwise residual analysis in two-way contingency tables. Educ Psychol Meas 63(5):825-839

Garcilazo JE, Martins JO, Tompson W (2010) Why policies may need to be place-based in order to be people-centred. VoxEU. Org, 20

Garud R, Karnøe P (2001) Path creation as a process of mindful deviation. In: Path dependence and creation. Earlbaum, , pp 1-38

Gibbs RM, Bernat GA Jr (1997) Rural industry clusters raise local earnings. Rural Am Dev Perspect $12: 18-25$

Glasmeier A (2000) Manufacturing time: global competition in the watch industry, 1795-2000. Guilford,

Granovetter M (1985) Economic action and social structure: the problem of embeddedness. Am J Sociol 91(3):481-510

Grillitsch M, Sotarauta M (2020) Trinity of change agency, regional development paths and opportunity spaces. Prog Hum Geogr 44(4):704-723

Hall CM (2005) Rural wine and food tourism cluster and network development. Rural Tour Sustain Bus 26:149-164

Harris JL (2020) Rethinking cluster evolution: actors, institutional configurations, and new path development. Prog Hum Geogr 45(3):436-454

Hashino T, Otsuka K (2013) Cluster-based industrial development in contemporary developing countries and modern Japanese economic history. J Jpn Int Econ 30:19-32

Hassink R, Isaksen A, Trippl M (2019) Towards a comprehensive understanding of new regional industrial path development. Reg Stud 11:1636-1645 
Hoang Thanh L, Ta Nhat L, Nguyen Dang H, Ho TMH, Lebailly P (2018) One Village One Product (OVOP) - A rural development strategy and the early adaption in Vietnam, the case of Quang Ninh Province. Sustainability 10(12):4485

Hogg MV (1978) Industrialization and rural development: an analysis of the basic issues. In: World conference on agrarian reform and rural development Rome, 12 July 1979 (UNIDO)

Huang Z, Zhang X, Yunwei ZHU (2008) The role of clustering in rural industrialization: a case study of the footwear industry in Wenzhou. China Econ Rev 19(3):409-420

Iammarino S, Rodriguez-Pose A, Storper M (2019) Regional inequality in Europe: evidence, theory and policy implications. J Econ Geogr 19(2):273-298

Isaksen A (2016) Cluster emergence: combining pre-existing conditions and triggering factors. Entrepreneursh Reg Dev 28(9-10):704-723

Jucevicius G, Grumadaite K (2015) Patterns for cluster emergence in latecomer economies. Procedia-social Behav Sci 213:198-203

Kenney M, Von Burg U (2001) Paths and regions: the creation and growth of Silicon Valley. In: Path dependence and creation, pp 127-148

Krugman PR (1991) Geography and trade. MIT Press, Cambridge London

Krugman P, Elizondo RL (1996) Trade policy and the third world metropolis. J Dev Econ. 49(1):137-150

Kurokawa K (2009) Effectiveness and limitations of the 'one village one product' (OVOP) approach as a government-led development policy: evidence from Thai 'one Tambon one product' (OTOP). Stud Reg Sci 39(4):977-989

Li N, Schumann FR (2013) The one village one product (OVOP) model and economic development on Guam. J Econ Econ Educ Res 14(3):21

Li E, Li X, Liu Z (2011) Relationships and evolving networks of rural manufacturing clusters: a case study in Yucheng County, Henan Province of China. Chin Geogr Sci 21(3):364-376

Lorenzen M (2005) Why do clusters change? Eur Urban Reg Stud 12(3):203-208

MacKinnon D, Dawley S, Pike A, Cumbers A (2019) Rethinking path creation: a geographical political economy approach. Econ Geog 95(2):113-135

Markusen A (1996) Sticky places in slippery space: a typology of industrial districts. Econ Geog 72(3):293-313

Marshall A (1920) Industry and trade

Martin R (2010) Roepke lecture in economic geography—rethinking regional path dependence: beyond lock-in to evolution. Econ Geog 86(1):1-27

Martin R, Sunley P (2006) Path dependence and regional economic evolution. J Econ Geogr 6(4):395-437

Menzel MP, Fornahl D (2010) Cluster life cycles-dimensions and rationales of cluster evolution. Ind Corp Change 19(1):205-238

Mokhayeri N, Taj S, Estelaji A, Langrodi MSH (2020) The effect of creation and development of completed industries on improving economic indicators in rural villages (study in Gorgan). J Stud Hum Settlements Plan 15(3):811-826

Mottaleb KA, Sonobe T (2013) The development process of rural informal industries in developing countries: the case of Bangladesh. J Dev Areas 47(2):229-249

Mukai K, Fujikura R (2015) One village one product: evaluations and lessons learnt from OVOP aid projects. Dev Pract 25(3):389-400

Natsuda K, Igusa K, Wiboonpongse A, Thoburn J (2012) One Village One Product-rural development strategy in Asia: the case of OTOP in Thailand. Can J Dev Stud. 33(3):369-385

Nylander M, Hall D (2005) Rural tourism policy: European perspectives. In: Hall DR, Kirkpatrick I, Mitchell M (eds). Rural tourism and sustainable business, vol 26. Channel view publications, pp $17-40$

Ohe Y (2019) Community-based rural tourism and entrepreneurship: a microeconomic approach. Springer,

Ohno A (2009) Rural clustering at incipient stages of economic development: hand-weaving clusters in Lao PDR. In: Reshaping economic geography in East Asia, pp 33-46

Ottati GD (1994) Cooperation and competition in the industrial district as an organization model. Eur Plan Stud 2(4):463-483

Pedersen PO (1997) Clusters of enterprises within systems of production and distribution: collective efficiency and transaction cost. In: van Dijk MP, Rabellotti R (eds) Enterprise clusters and networks in developing counties. Frank Cass, London, pp 11-29

Pilon S, De Bresson C (2003) Local culture and regional innovation networks: some propositions. In: Brenner T, Fornahl D (eds) Cooperation, networks and institutions in regional innovation systems. Edward-Edgar, Cheltenham, pp 15-37

Porter ME (1990) The competitive advantage of nations. Compet Intell Rev 1(1):14-14 
Porter ME (1998) On competition. Harvard Business School Press, Boston

Porter ME (2000) Location, competition, and economic development: local clusters in a global economy. Econ Dev Q 14(1):15-34

Rodrik D (2005) Growth strategies. In: Aghion P, Durlauf S (eds) Handbook of economic growth, vol 1. Elsevier, , pp 967-1014

Rodríguez-Pose A, Ketterer T (2020) Institutional change and the development of lagging regions in Europe. Reg Stud 54(7):974-986

Sato Y (2000) Linkage formation by small firms: the case of a rural cluster in Indonesia. Bull Indones Econ Stud 36(1):137-166

Scott AJ (1988) Flexible production systems and regional development. Int J Urban Reg Res 12(2):171-186

Scott AJ, Storper M (1987) Industrial change and territorial organization. Allen and Unwin, London

Sega NJ, Kanichiro S (2018) The OVOP as a tool to develop small and medium-size enterprises: insights from OVOP entrepreneurial experience in Senegal. Int J Educ Res 6(3):95-112

Sengenberger W, Pyke F (1990) Small firm industrial districts and local economic regeneration: research and policy issues. International Labor Organization

Sforzi F (1989) The geography of industrial districts in Italy. In: Small firms and industrial districts in Italy, pp 153-173

Sopoligová M, Pavelková D (2017) Cluster policy in europe and asia: a comparison using selected cluster policy characteristics. J Int Stud 10(3):35-50

Statistical Center of Iran (2019) Abstract results of the labor force survey in 2019-2018. Population, Labor, and Census Bureau at Statistical Center of Iran, pp 1-15

Stephens HM, Partridge MD (2011) Do entrepreneurs enhance economic growth in lagging regions? Growth Change 42(4):431-464

Storper M (1995) The resurgence of regional economies, ten years later: the region as a nexus of untraded interdependencies. Eur Urban Reg Stud 2(3):191-221

Trippl M, Grillitsch M, Isaksen A (2018) Exogenous sources of regional industrial change: attraction and absorption of non-local knowledge for new path development. Prog Hum Geogr 42(5):687-705

Viederytė R (2018) Cluster life cycles: types and driving factors. Reg Form Dev Stud 24(1):62-72

Voronkova OY, Iakimova LA, Frolova II, Shafranskaya CI, Kamolov SG, Prodanova NA (2019) Sustainable development of territories based on the integrated use of industry, resource and environmental potential. Int J Econ Bus Administration 7(2):151-163

Wardenburg S, Brenner T (2020) How to improve the quality of life in peripheral and lagging regions by policy measures? Examining the effects of two different policies in Germany. J Regional Sci 60(5):1047-1073

Weijland H (1994) Trade networks for flexible rural industry. In: Pedersen PO, Sverrisson A, van Dijk MP (eds) Flexible specialization: the dynamics of small-scale industries in the south. Intermediate Technology Publications, London

Zeitlin J (1992) Industrial districts and local economic regeneration: overview and comment. In: Industrial districts and local economic regeneration, pp 279-294

Publisher's Note Springer Nature remains neutral with regard to jurisdictional claims in published maps and institutional affiliations. 